\title{
Directors' and officers' liability insurance and loan spreads
}

\author{
Chen Lin, Micah Officer ${ }^{\curlyvee}$, Rui Wang, Hong Zou
}

\begin{abstract}
We analyze the effect of directors' and officers' liability insurance (D\&O insurance) on the spreads charged on bank loans. We find that higher levels of D\&O insurance coverage are associated with higher loan spreads and that this relation depends on loan characteristics in economically sensible ways and is attenuated by monitoring mechanisms. This association between loan spreads and $\mathrm{D} \& \mathrm{O}$ insurance coverage is robust to controlling for endogeneity (because both could be related to firm risk). Our evidence suggests that lenders view D\&O insurance coverage as increasing credit risk (potentially via moral hazard or information asymmetry). Further analyses show that higher levels of D\&O insurance coverage are associated with greater risk taking and higher probabilities of financial restatement due to aggressive financial reporting. While greater use of $\mathrm{D} \& \mathrm{O}$ insurance increases the cost of debt, we find some evidence that $\mathrm{D} \& \mathrm{O}$ insurance coverage appears to improve the value of large increases in capital expenditure for firms with better internal and external governance.
\end{abstract}

\section{JEL classification: G30, G22}

Keywords: Directors' and officers' liability insurance; loan spreads; credit risk; cost of debt financing

\footnotetext{
* We would like to thank Mike Adams, Ji-Woong Chung, and Mike Hertzel, conference participants at the 2011 City University International Conference on Corporate Finance, and seminar participants at California State University Fullerton, Singapore Management University, Southwestern University of Finance and Economics, the University of Hong Kong, the University of International Business and Economics, and the University of Melbourne for helpful comments. Research assistance of Joy Li is appreciated. Lin acknowledges financial support from the Research Grants Council of the Hong Kong Special Administrative Region, China (Project No. T31/717/12R). Zou acknowledges financial support from a GRF grant from Research Grants Council of the Hong Kong Special Administrative Region, China (Project No. 154811).

$\diamond$ Corresponding author. Loyola Marymount University, E-mail address: micah.officer@lmu.edu
} 


\section{Introduction}

Most public companies in the US and Canada carry directors' and officers' (D\&O) liability insurance. ${ }^{1}$ A practitioner survey carried out in 2007 found that $87 \%$ of the 356 directors polled rank the availability of comprehensive $D \& O$ insurance coverage as an important consideration before agreeing to join a board. ${ }^{2}$

A typical D\&O insurance policy is purchased by a company to protect its directors and officers from personal liability in the event of litigation brought by shareholders or other stakeholders (e.g., creditors) alleging wrongdoing in discharging their duties. Despite its popularity, D\&O insurance is not without controversy, and there is little evidence about how the purchase of this insurance is perceived by a company’s stakeholders. In particular, because D\&O insurance insulates directors and officers from the threat of litigation and personal financial liability resulting from their decisions on behalf of the corporation, ${ }^{3} \mathrm{D} \& \mathrm{O}$ insurance could induce unintended moral hazard and reduce the incentive of managers to act in the best interest of stakeholders (Chung and Wynn, 2008; and Lin, Officer, and Zou, 2011).

In this study we investigate how lenders perceive D\&O insurance coverage by examining the impact of D\&O insurance coverage on a firm's cost of debt and whether offsetting effects exist for other corporate stakeholders. We examine the effects of D\&O insurance coverage on the spreads in bank loans because bank lending represents an important source of corporate financing and lenders are important corporate stakeholders. Risk (particularly moral hazard) and information asymmetry are two important factors shaping loan contracts (Graham, Li, and Qiu, 2008), and D\&O insurance coverage has the potential to influence both. On the one hand, the existence of D\&O insurance could lower a company’s cost of bank loans (i.e., loan spreads) because the coverage could lower a firm's default risk and the insurance payout may be

\footnotetext{
${ }^{1}$ See Baker and Griffith (2010) for statistics in the US and Egri, Gordon, and Shapiro (2006) for figures in Canada.

${ }^{2}$ See "The Directors \& Boards Survey: D\&O Insurance" in Boardroom Briefing, Volume 4, No. 1, a publication of Directors \& Boards Magazine and GRID Media LLC.

${ }^{3}$ We discuss indemnification later in the paper.
} 
considered part of a company's asset base at the time of bankruptcy (Donley and Kent, 2008). Prior studies (Mayers and Smith, 1982, 1990; Core, 1997; and Zou and Adams, 2008) argue that insurance (including D\&O insurance) constitutes an integral part of a company's risk management. $^{4}$

On the other hand, D\&O insurance shields directors and officers from lawsuits brought by shareholders and others, thereby lowering the deterrent effect of litigation. D\&O insurance could, therefore, increase a firm's loan spreads if protected directors and officers who have little at stake in the event of litigation engage in more risk taking in pursuit of their own private objectives (Jensen and Meckling, 1976) or if reduced vigilance leads to low-quality financial reporting (also potentially driven by the desire to conceal opportunistic behavior). Rational lenders would price-protect themselves against higher default and recovery risk by demanding higher loan spreads.

Using D\&O insurance data for a sample of Toronto Stock Exchange (TSE) 300 Index (currently the S\&P/TSX Composite Index) constituent stocks and (syndicated) bank loan data from the Loan Pricing Corporation (LPC) DealScan database, we find that high levels of D\&O insurance coverage are associated with higher loan spreads and that these results are robust to the inclusion of a variety of control variables (including firm fixed effects). Specifically, a onestandard-deviation increase in the ratio of the $\mathrm{D} \& \mathrm{O}$ insurance coverage limit scaled by the market value of equity increases loan spreads by about 19 basis points on average, with these estimates being statistically and economically significant.

In this context, endogeneity is obviously a concern. Specifically, one might be concerned that $\mathrm{D} \& \mathrm{O}$ insurance coverage and loan spreads spuriously appear related because they are both

\footnotetext{
${ }^{4}$ Boyer (2005) also argues that the role of D\&O insurance is to provide a last-chance payment for shareholders who suffer financially due to managerial wrongdoings. On the other hand, Baker and Griffith (2010) argue that D\&O policy limits are often small relative to firm size (though significant compared with the personal wealth of directors and officers) and, hence, D\&O insurance might not effectively lower the chance of insolvency. The mean policy limit in our sample is about $6.5 \%$ of the market value of equity.
} 
(endogenously) driven by fundamental firm risk: directors of riskier firms are likely to demand greater levels of $\mathrm{D} \& \mathrm{O}$ insurance protection against the cost of litigation and their firms are charged higher loan spreads by banks (because the firms are riskier). To address this concern, we employ a multitude of different strategies, including a substantial battery of variables to control for risk in our regressions explaining loan spreads (specifically firm-level cash flow volatility, industry fixed effects, and credit rating indicator variables), as well as an instrumental variable (IV) estimation.

To further alleviate the concern about endogeneity, we employ change regressions examining the effect of a change in D\&O insurance coverage on the change in loan spreads. The change regression framework helps account for time-invariant omitted firm characteristics (such as unobservable risk) that could affect both the level of D\&O insurance coverage and the cost of bank loans (Lin, Ma, Malatasta, and Xuan, 2011). Our empirical results remain economically and statistically significant in this change regression specification. Moreover, we use an exogenous (regulatory) event that expands civil liability of directors and officers to further identify the relation between $\mathrm{D} \& \mathrm{O}$ insurance and the cost of bank loans.

To drill further down into this relation, we explore the channels through which agency costs induced by D\&O insurance coverage at the borrowing firm could be exacerbated or mitigated. We find that the effect of $\mathrm{D} \& \mathrm{O}$ insurance coverage on loan spreads is more pronounced in term loans, loans with long maturity, and loans taken out for acquisition purposes. In contrast, the effect of $\mathrm{D} \& \mathrm{O}$ insurance coverage on loan spreads is less pronounced for firms with robust external monitoring mechanisms. Specifically, we find that monitoring mechanisms such as greater analyst following, the presence of a blockholder in the ownership structure, and the existence of a prior lending relation between the borrower and the lead bank (in the syndicate) help attenuate the effect of $\mathrm{D} \& \mathrm{O}$ insurance on loan spreads.

Guided by debt contracting theory, we then seek to understand why banks charge higher spreads to borrowers with higher $\mathrm{D} \& \mathrm{O}$ insurance coverage. Specifically, we examine two channels: the effect of $\mathrm{D} \& \mathrm{O}$ insurance on corporate risk taking and the effect of $\mathrm{D} \& \mathrm{O}$ insurance 
on the quality of financial reporting. First, we find that high levels of D\&O insurance coverage increase firms' total and idiosyncratic risk, strongly suggestive of greater risk taking as a channel by which D\&O insurance coverage affects the cost of debt. Second, because over 50\% of the securities class actions in Canada between 1992 and 2008 involve financial restatements by the defendant company (Pritchard and Sarra, 2010), we examine earnings restatements and find that firms with higher levels of $\mathrm{D} \& \mathrm{O}$ insurance coverage are more likely to restate earnings. Firms with higher levels of D\&O insurance coverage are also more likely to have restatements caused by prior intentional misstatements.

Taken together, our results suggest that banks associate higher D\&O insurance coverage with greater default or recovery risk, which are then reflected in the terms at which lenders provide loans to the firm. This appears to be a rational association, because higher $\mathrm{D} \& \mathrm{O}$ insurance coverage does appear to lead to greater risk taking (moral hazard) and lower quality financial reporting (information asymmetry). Our evidence is also consistent with the argument that banks value external monitoring mechanisms (analysts, blockholders) in attenuating the adverse effects of high levels of D\&O insurance coverage.

Our evidence speaks to a cost of providing D\&O insurance. D\&O insurance, however, could help firms attract competent and risk-averse individuals to serve as directors and officers and motivate them to avoid overly conservative investment choices that are suboptimal for shareholders (e.g., Bhagat, Brickley, and Coles, 1987; and Core, 1997). As argued in the literature (e.g., Amihud and Lev, 1981; Hirshleifer and Thakor, 1992; Holmstrom and Ricart I Costa, 1986; Bertrand and Mullainathan, 2003; and Bradley and Chen, 2011), managers have incentives to avoid risk taking and even forgo value-enhancing risky projects to protect their career and enjoy the quiet life. This risk-aversion could be exacerbated by the fact that managers' financial and human capital is inevitably concentrated within the firms they control (John, Litov, and Yeung, 2008).

With the protection of personal wealth from shareholder suits provided by D\&O insurance coverage, managers’ and directors’ investment choices might be less conservative and 
closer to optimal choices from the perspective of shareholders. We expect that this benefit from the provision of D\&O insurance coverage would be reflected in the value of a firm's investment, and the effect should be more pronounced in firms with good corporate governance. Using the analytical framework of Faulkendar and Wang (2006) and Masulis, Wang, and Xie (2009), we examine the marginal value of large increase in capital expenditures. Generally consistent with our conjecture, we find moderate evidence that $\mathrm{D} \& \mathrm{O}$ insurance appears to improve the marginal value of investment when there is strong monitoring by independent directors or product market competition, though its effect on firm performance is negative on average. ${ }^{5}$ These results add to an understanding about the beneficial role that D\&O insurance might play in affecting corporate policies and outcomes under certain circumstances.

We contribute to the extant literature in several ways. First, to our knowledge, our study is the first to examine how D\&O insurance, commonly purchased by companies, affects debtholders and the pricing of loan contracts. Second, our evidence identifies specific channels through which D\&O insurance could affect firm value and, therefore, our paper also contributes to the growing literature on the corporate governance aspects of D\&O insurance (e.g., Core, 2000; Baker and Griffith, 2007; Gillan and Panasian, 2010; Lin, Officer, and Zou, 2011; and Boyer and Stern, 2012). Third, this paper adds to the debt contracting literature that has examined the determinants and consequences of various debt contracting terms (e.g., Graham, Li, and Qiu, 2008; Bradley and Chen, 2011; Lin, Ma, Malatesta, and Xuan, 2011; and Hertzel and Officer, 2012). Our findings uncover a new factor (i.e., D\&O insurance) that systematically appears to affect corporate lenders and loan terms. Fourth, our paper is also broadly related to the literature on the effects of litigation risk on corporate behavior (e.g., Lowry and Shu, 2002; and Lowry, Field, and Shu, 2005). These studies show that litigation risk affects underpricing and voluntary disclosure in initial public offerings. Our results that D\&O insurance mutes the effect

\footnotetext{
${ }^{5}$ This negative average effect of D\&O insurance coverage corroborates evidence on the managerial opportunism and unintended moral hazard effect of D\&O insurance reported in prior studies (e.g., Chalmers, Dann, and Harford, 2002; Chung and Wynn, 2008, Wynn, 2008; and Lin, Officer, and Zou, 2011).
} 
of litigation risk and leads to greater probabilities of financial restatement and greater risk taking complement this literature.

We organize the remainder of the paper as follows. In Section 2, we briefly review D\&O insurance in Canada. We describe our data in Section 3. Sections 4 through 7 report our empirical results. Section 8 concludes.

\section{D\&O insurance in Canada}

The liability risk to corporate directors and officers in Canada can come from shareholder litigation or lawsuits brought by other parties (e.g., creditors, regulators). Similar to that in the US, directors and officers in Canada can be sued under the corporate law for breach of fiduciary duties (i.e., duty of care and acting honestly and in good faith) or under the securities law, with the latter being the most significant source of risk (Donley and Kent, 2008). Securities lawsuits can target disclosure irregularities in the course of securities offerings (i.e., primary market liability suits) or in continuous disclosure (i.e., secondary market liability suits), and the system for handling class action securities lawsuits in Canada resembles that in the US to a large extent (at least since 1992; Pritchard and Sarra, 2010).

The Canada Business Corporation Act (CBCA), the 1985 corporate law enacted at the federal level, allows a company to indemnify its directors and officers for legal costs via bylaws or charters as long as directors and officers have acted in good faith and in the best interests of the company. Upon the approval of a court, a Canadian company could indemnify its directors and officers for the cost of defense in shareholder derivative suits, but for neither settlement nor judgment. By virtue of this, Canadian public companies routinely indemnify directors and officers for legal liability (Cheffins and Black, 2006).

Nevertheless, D\&O insurance provides protection that is distinct from indemnification in the following ways. First, D\&O insurance protects directors and officers when their company cannot indemnify them due to legal restrictions, insolvency, or when a company declines to indemnify them. This is known as Side-A coverage. Second, Side-B coverage allows a company 
to recover the cost it incurs in indemnifying its directors and officers. The policy limits of these types of coverage are typically equal, although Side-B coverage often has a deductible (an amount that is to be borne by the insured company) while Side-A coverage (for the personal directors) typically does not.

Directors and officers consider D\&O insurance coverage to be crucial and irreplaceable for many reasons, including the fact that the costs of settlement or judgment in derivative suits are typically covered by a D\&O insurance policy (Chalmers, Dann, and Harford, 2002). Furthermore, the exclusions that apply to $\mathrm{D} \& \mathrm{O}$ insurance coverage (i.e., deliberate fraud and illegal profit by directors and officers) are much narrower compared with the requirement of acting in good faith and in the best interests of the company associated with corporate indemnification (Cheffins and Black, 2006). Perhaps even more important, D\&O policy exclusions in practice do not constitute an obstacle as either they need to be established by final adjudication or because plaintiff lawyers can strategically avoid referring to them in pleading (Baker and Griffith, 2010). D\&O insurers usually pay out on a policy as long as the defendants (directors and officers) do not admit to fraud or illegal profit (Baker and Griffith, 2010). Surveys of board members and executives confirm the conclusion that D\&O insurance is considered valuable (and maybe even essential) in spite of the fact that companies can (and routinely do) indemnify them. ${ }^{6}$

\section{Data and sample selection}

Empirical research about the effect of D\&O insurance on stakeholders is often hampered by the lack of data on firm-level purchases of $\mathrm{D} \& \mathrm{O}$ insurance. In this paper, we examine Canadian public companies as disclosure of the details of $\mathrm{D} \& \mathrm{O}$ insurance purchases is mandatory in Canada. We focus on constituent firms of the TSE 300 Index (currently S\&P/TSX Composite Index) during 1996-2008. We hand-collect firm-level D\&O insurance information

\footnotetext{
${ }^{6}$ See “The Directors \& Boards Survey: D\&O Insurance” article referred to in footnote 2.
} 
(i.e., the existence of $\mathrm{D} \& \mathrm{O}$ insurance, coverage, premium, and deductibles) from proxy circulars in the System for Electronic Document Analysis and Retrieval (SEDAR) database. ${ }^{7}$

We also collect information on corporate governance (e.g., ownership structure, board structure, and executive compensation) from annual corporate filings. Syndicated bank loan data are extracted from LPC's DealScan database and our loan data end in 2008. We then match our D\&O insurance information with loan data to arrive at the sample for the loan spread analysis. ${ }^{8}$ D\&O insurance information is lagged by one year relative to loan data so that the $\mathrm{D} \& \mathrm{O}$ insurance purchase can be assumed to be predetermined and can have its effect (if any) show up in subsequent loan contracting. Our analysis of loan spreads is at the loan level. In DealScan, this is referred to as a facility. We exclude financial firms from our analysis and exclude loans with missing spreads. Our final sample contains 615 loans drawn by 186 firms. Accounting data are taken from Compustat. We also obtain from Institutional Brokers' Estimate System (I/B/E/S) data on analysts' following and use them in our analysis.

Descriptions of the variables used in our analyses are contained in Table 1. Below we describe the most important variables in detail.

[Insert Table 1 near here]

\subsection{D\&O insurance}

We first examine the relation between $\mathrm{D} \& \mathrm{O}$ insurance and loan spreads by using indicator variables to split the sample to see general patterns. However, it could be argued that indicator variables are coarse measures, and so we follow the literature (e.g., Chalmers, Dann,

\footnotetext{
${ }^{7}$ See www.sedar.com. We calculate a time-weighted-average amount of coverage limit as the coverage limit in a fiscal year by considering different $\mathrm{D} \& \mathrm{O}$ insurance policy-periods that fall in the fiscal year concerned. If a firm's proxy circular is unavailable, we treat $\mathrm{D} \& \mathrm{O}$ insurance variables as missing.

${ }^{8}$ We first use the link file maintained by Michael Roberts to match our data to DealScan records and then manually check the unmatched ones.
} 
and Harford, 2002; and Lin, Officer, and Zou, 2011) and use the (continuous) insurance coverage ratio as our measure of the extent of $\mathrm{D} \& \mathrm{O}$ insurance in most of our regressions. This variable is defined as the personal (Side-A) coverage limit of the D\&O insurance policy scaled by the market value of equity of the firm at the end of the concurrent fiscal year. We set this variable equal to zero if a firm does not have $\mathrm{D} \& \mathrm{O}$ insurance in a given year. We winsorize the insurance coverage ratio at the first percentile in the right tail and other firm-level controls at $1 \%$ in both tails to mitigate the undue influences of outliers. Summary statistics can be found in Table 2. As can be seen from the table (Panel A), approximately $72 \%$ of the loans in our sample are originated by firms whose directors are protected by $\mathrm{D} \& \mathrm{O}$ insurance. The personal coverage limit on average represents $6.5 \%$ of the issuing firm's market value of equity in the sample.

\section{[Insert Table 2 near here]}

\subsection{Cost of bank loans}

Following the literature (e.g., Carey and Nini, 2007; Graham, Li, and Qiu, 2008; Lin, Ma, Malatesta, and Xuan, 2011; and Hertzel and Officer, 2012), we use the all-in-drawn spread from DealScan to measure the cost of bank loans. This measure is defined as the spread over the London Interbank Offered Rate (LIBOR) (or LIBOR equivalent) on a loan plus associated loan origination fees. ${ }^{9}$ The loan spread is measured at the origination of a loan. According to Table 2 (Panel A), the average loan spread is 182 basis points.

\footnotetext{
${ }^{9}$ Syndicated loans typically have floating interest rates in which the interest paid is specified in the contract as a market-based benchmark rate plus a spread (Carey and Nini, 2007). In DealScan, fixed rate loans account for a minor fraction of all syndicated loans (less than $10 \%$ of the total number of loans). In addition, the all-in-drawn spread is missing for all fixed rate loans. This is why prior studies use only floating rate loans with non-missing allin-drawn spreads (e.g., Carey and Nini, 2007). We also follow this convention. For floating rate loans not based on LIBOR, DealScan converts the coupon spread into a LIBOR spread by adding or subtracting a constant differential reflecting the historical averages of the relevant spreads (see Hertzel and Officer, 2012).
} 


\subsection{Control variables}

To examine the impact of D\&O insurance on loan spreads, we follow the literature (e.g., Graham, Li, and Qiu, 2008; and Hertzel and Officer, 2012) and control for other firm-specific and contract-specific factors that might affect loan spreads. All firm-specific variables enter our regressions with a one-year lag from the year in which the loan is originated, which ensures that these characteristics are at least exogenous in time. For robustness, all our regressions also include either or both industry and year fixed effects to attempt to capture heterogeneity between loans that is unrelated to observable firm- and loan-level characteristics.

In terms of firm characteristics, we control for firm size (measured using assets), marketto-book ratio, profitability, asset tangibility, cash flow volatility, and leverage. Firm size decreases information asymmetry problems in credit markets and, as a consequence, likely reduces loan spreads. Asset tangibility increases recovery rates in default and, therefore, should also be negatively associated with loan spreads. Moreover, profitable, low-leverage firms, and firms with stable cash flows, are less likely to default and these characteristics are expected to be associated with lower loan spreads (Lin, Ma, Malatesta, and Xuan, 2011). For the market-tobook ratio, our prediction is less clear. On the one hand, as a proxy for growth opportunities, the market-to-book ratio could indicate a higher likelihood of risk shifting activities. On the other hand, it could proxy for additional value (over liquidation) that is left for creditors in distress (Graham, Li, and Qiu, 2008).

Corporate governance could also affect loan spreads. As discussed in the literature (e.g., Shleifer and Vishny, 1997), corporate governance mechanisms might attenuate the agency costs of debt. Therefore, we also control for board characteristics [the proportion of independent directors and chief executive officer (CEO)-chairman duality] and ownership structure (two indicator variables to control for dual-class share structure and blockholders) in our regressions. Dual-class share structures enable corporate insiders to exercise effective control over a company with a relatively small direct stake in the cash flow rights (Lin, Ma, Malatesta, and Xuan, 2011). In such firms, corporate insiders have incentives to expropriate minority shareholders and 
creditors, through various tunneling and self-dealing activities. ${ }^{10}$ Many of these activities increase default risk and, thereby, the cost of loans. Blockholders also play an important governance role as they are more informed than retail investors and have strong incentives and capabilities to devote resources to monitoring (Shleifer and Vishny, 1997). We collect blockholding and other governance data from proxy circulars, and our indicator variable captures the existence of a blockholder with greater than $10 \%$ of the firm's shares.

We also include in our model for loan spreads a proxy for product market competition as an external governance mechanism. Recent studies (e.g., Giroud and Muller, 2011) have shown that product market competition could be an effective external governance mechanism that helps reduce managerial slack and improve firm performance. Banks are likely to charge lower loan spreads to firms operating in competitive product markets if market competition alleviates managerial agency problems and improves firm performance. However, firms operating in concentrated industries (i.e., less competition) also could have lower risk and, therefore, pay lower loan interest rates. The effect of product market competition on loan spread is thus an empirical issue.

We control for contract-specific characteristics that could affect the cost of loan contracting. Specifically, we control for loan size and the presence of a performance pricing clause. Moreover, we include indicator variables to control for loan type (term loans or revolvers) and purpose (working capital or general corporate purposes, refinancing, acquisition, commercial paper backup, or others), and we also include detailed indicator variables for the borrower's Standard \& Poor’s (S\&P) credit rating category (firms without ratings are the omitted group).

It is important to note that many firm characteristics are also likely to affect firms’ D\&O insurance purchase decisions. Specifically, large and highly profitable firms could purchase more

\footnotetext{
${ }^{10}$ These activities include outright theft, diverting firm resources for their own use, executive perquisites, expropriation of corporate opportunities, committing funds to unprofitable projects that provide private benefits, transferring assets and profits out of companies, loan guarantees using the firm's assets as collateral, and other selfdealing financial transactions (Shleifer and Vishny, 1997).
} 
D\&O insurance than do small (or loss-making) firms because they are more likely to be targeted by shareholders or entrepreneurial lawyers. However, large and profitable firms could have greater financial capacity to absorb liability and so could choose to purchase less D\&O insurance (and protect directors via indemnity) than smaller firms if self-insurance is more efficient than actuarially unfair D\&O insurance. ${ }^{11}$ Firms with high cash flow volatility, leverage, and growth opportunities are riskier than other firms and are, therefore, likely to have a higher demand for D\&O insurance coverage (Core, 1997).

Corporate governance could affect the demand for D\&O insurance in three ways. First, close monitoring afforded by good governance should lower litigation risk and reduce the demand for D\&O insurance (Baker and Griffith, 2007; and Gillan and Panasian, 2010). Second, the purchase of D\&O insurance can be induced by managers' opportunism (Core, 1997; Chalmers, Dann, and Harford, 2002), and good corporate governance could limit such opportunistic purchases. Third, to the extent that $\mathrm{D} \& \mathrm{O}$ insurers also play a monitoring role in corporate governance (Holderness, 1990), firms with other corporate governance mechanisms (e.g., independent directors, blockholders, the separation of CEO and board chairman) could have less need to purchase $\mathrm{D \& O}$ insurance for monitoring purposes. It is also important to note that firms with a more independent board (i.e., better governance) might need to offer D\&O insurance coverage to help attract and retain able, but risk-averse, independent directors. Prior studies (e.g., Core, 1997; and Chalmers, Dann, and Harford, 2002) typically find that more independent directors lead to the purchase of more D\&O insurance coverage, suggesting that the demand for insurance by independent directors tends to dominate the monitoring motive.

While a full prediction model for D\&O insurance purchases is beyond the scope of this paper, the coefficient on the insurance coverage ratio in our loan spread regressions could be biased if we do not offer adequate controls for factors that could covary with D\&O purchase decisions. For this reason, our loan spread regression models contain a battery of controls for

\footnotetext{
${ }^{11}$ D\&O insurance premiums contain significant portions of expense and profit loading in addition to the actuarial cost of risk (Zou, 2010).
} 
firm-specific characteristics, including firm size, corporate governance, profitability, and numerous controls for risk.

\subsection{Univariate analysis}

Before conducting regression analysis in Section 4, we first look at univariate statistics to identify broad patterns in the data. We split the sample into three groups: a group without D\&O insurance (i.e., the zero coverage group) and two subgroups for firm-years with $\mathrm{D} \& \mathrm{O}$ insurance. These two subgroups are a group with below-median coverage within the sample of firm-years with $\mathrm{D} \& \mathrm{O}$ insurance (moderate coverage) and a group with above-median coverage within the sample of firm-years with $\mathrm{D} \& \mathrm{O}$ insurance (high coverage). We then compare the mean values of loan spreads between the high coverage and zero coverage groups. The results are presented in Panel B of Table 2. The average loan spread for firms in the high coverage group is 240 basis points, while the average loan spread for firms in the zero coverage group is 152 basis points. The difference is statistically significant. This positive relation between D\&O insurance coverage and loan spreads paid by corporate borrowers suggests that high $\mathrm{D} \& \mathrm{O}$ insurance coverage is perceived by lenders as being associated with a higher borrower risk.

We also divide the sample into groups of firms with insurance coverage ratio above or below the sample median and into groups with and without insurance. We find a similar pattern in the relation between insurance coverage and average loan spread as discussed above. However, we do not find significant differences in firm characteristics for syndicated loan borrowers with and without $\mathrm{D} \& \mathrm{O}$ insurance except that insured borrowers have lower asset tangibility. To gain more insight, we focus on the firms with $\mathrm{D} \& \mathrm{O}$ insurance and divide the sample into firms that borrow from syndicated loan market and those that do not. For firms with D\&O insurance, syndicated loan borrowers are larger, more profitable, have lower cash flow volatility, use more debt, have more tangible assets, have a more independent board, and have a lower market-tobook ratio than non-borrowers. These characteristics are typical of firms that access syndicated 
loans. ${ }^{12}$ This comparison also shows the importance of controlling for these factors in our loan spread regressions. In fact, as illustrated in our loan spread regressions, borrowers that are larger, more profitable, and have lower cash flow volatility tend to have lower costs of borrowing.

\section{Regression results}

In this section, we use regression analysis to examine the effects of $\mathrm{D} \& \mathrm{O}$ insurance on loan spreads.

\subsection{The effect of $D \& O$ insurance coverage on loan spreads}

The main empirical model we estimate is:

Loan spread $=f(D \& O$ insurance coverage, Borrower characteristics, Governance measures, Loan characteristics, Year and industry fixed effects)

In Eq. (1), the dependent variable is the all-in-drawn loan spread measured in percentage points. The key independent variable of interest is $\mathrm{D} \& \mathrm{O}$ insurance coverage. We first use two D\&O insurance indicators denoting the moderate coverage and high coverage groups described in Section 3. Therefore, the zero coverage group is the omitted category. The use of indicator variables to capture $\mathrm{D} \& \mathrm{O}$ insurance coverage might be a blunt instrument relative to the use of a continuous D\&O insurance coverage ratio as an independent variable. While we use indicator variables in our baseline regressions to demonstrate that the positive association between coverage and loan spreads is not driven by outliers, in later tables we employ the (continuous) D\&O insurance coverage ratio.

The empirical results from using insurance coverage indicators are presented in Table 3, which contains four regressions. We include in the models controls for borrower characteristics, board structure, ownership structure, product market competition, and loan characteristics, as

\footnotetext{
${ }^{12}$ For brevity, these results are not tabulated but are available upon request.
} 
well as borrower industry and year fixed effects. The first specification controls for a set of borrower characteristics and credit rating indicators, and the second regression adds controls for loan size and the performance pricing indicator. The third model adds controls for loan type and loan purpose, and the fourth regression adds a set of governance variables and year fixed effects.

[Insert Table 3 near here]

As can be seen from the table, the high coverage group pays higher loan spreads than the zero coverage group. This is evidenced by the positive and statistically significant coefficients on the high coverage indicator. Hence, even these coarse measures of D\&O insurance coverage provide some evidence that higher levels of $\mathrm{D} \& \mathrm{O}$ insurance coverage are associated with higher loan spreads. The coefficients on the moderate coverage indicators are positive but insignificant, suggesting that low, but positive, coverage is not associated with loan spreads higher than those for firms with no coverage at all.

Regarding the control variables, the empirical results are largely consistent with prior literature (e.g., Graham, Li, and Qiu, 2008; and Hertzel and Officer, 2012). Specifically, we find that larger borrower size, higher profitability, lower leverage, and lower cash flow volatility tend to be associated with significantly lower loan spreads. We also find strong evidence that larger loan issues are associated with lower spreads, consistent with the economies of scale in loan contracting. We next use the continuous $\mathrm{D} \& \mathrm{O}$ insurance coverage ratio to examine the effects of D\&O insurance on loan spreads, and the results are reported in Table 4.

\section{[Insert Table 4 near here]}

As can be seen from Table 4, the empirical results are consistent with our previous findings. Across all model specifications, we find a positive and significant relation between the D\&O insurance coverage ratio and loan spreads, indicating that firms whose directors and officers have greater $\mathrm{D} \& \mathrm{O}$ coverage pay higher borrowing costs in the syndicated loan market. 
Specifically, a one-standard-deviation increase in the insurance coverage ratio increases loan spreads by about 19 basis points on average (based on the coefficient point estimates in Column 4), ceteris paribus. Considering the average loan spread is 182 basis points, this represents about a $10 \%$ increase. Therefore, the effect of $\mathrm{D} \& \mathrm{O}$ insurance on loan spreads is both economically meaningful and statistically significant. To our knowledge, this is the first evidence in the literature showing that corporate lenders appear to price the borrower's D\&O insurance coverage when contracting over new loans.

With respect to the control variables in Table 4, the empirical results are largely consistent with our expectations (and the results in Table 3). For instance, we find that firm size and profitability are negatively associated with loan spreads; cash flow volatility and leverage are positively associated with loan spreads in all specifications. A higher degree of tangibility is also (weakly) associated with lower loan spreads in the regression in Column 2, suggesting that the collateral recovery rate matters for loan pricing to a certain degree.

\subsection{Factors moderating the effect of $D \& O$ insurance coverage on loan spreads}

Our results thus far suggest that bank lenders appear concerned that D\&O insurance coverage exacerbates credit risk and agency costs. Agency costs, for example, could be created by the possibility that the shield from personal financial liability provided by $\mathrm{D} \& \mathrm{O}$ insurance encourages directors and officers of the borrower to shirk from their duties or to take greater risk than otherwise expected. In this subsection, we examine whether loan terms and (internal and external) monitoring mechanisms affect the relation between D\&O insurance and loan spreads. The idea is that the structure of loan contracts and the existence of alternate monitoring mechanisms might moderate the credit risk and monitoring costs faced by lenders, attenuating the effect of D\&O insurance coverage on loan spreads.

The loan attributes we examine include loan maturity, loan type, and loan purpose. ${ }^{13}$ Banks face higher credit risk in making a loan with long maturity than one with short maturity.

\footnotetext{
${ }^{13}$ We thank an anonymous referee for this suggestion.
} 
Term loans are also riskier for the lending banks than revolving loans are, explaining why borrowers pay higher spreads on term loans in our sample. When a loan is taken out for the purpose of launching an acquisition, banks face higher credit risk because many acquisitions are value destroying (Moeller, Schlingemann, and Stulz, 2004) ${ }^{14}$ We expect that these loans are more sensitive to the moral hazard induced by D\&O insurance and its effect on loan spreads.

In Panels A-C of Table 5, we conduct split-sample analyses of the relation between D\&O insurance coverage and loan spreads. In each case, the regression resembles the model reported in Column 4 of Table 4, but we suppress the majority of the coefficients (for brevity) and report just the coefficient on the continuous D\&O insurance coverage ratio. In Panel A, we first split the sample by whether the loan has maturity less than five years or not. The coefficient on the insurance coverage ratio is positive and statistically significant at the 0.01 level for the long maturity group and insignificant in the short maturity group. This provides support for the argument that banks are more vulnerable to the agency problems induced by borrower D\&O insurance when making long maturity loans and that this leads banks to charge a higher loan spread to price-protect themselves.

\section{[Insert Table 5 near here]}

We then compare the regression coefficients on the insurance coverage ratio for term loans and non-term loans (Panel B) and for loans borrowed for acquisition purposes and other purposes (Panel C). The results suggest that the magnitude of the effect of D\&O insurance coverage on loan spreads is larger for term loans than non-term loans, and larger in loans for acquisitions than for other purposes. Unreported tests demonstrate that the differences in the relevant coefficients are statistically significant at the 0.05 level or better. These results are all broadly consistent with the notion that the sensitivity of loan spreads to D\&O insurance coverage

\footnotetext{
${ }^{14}$ Moreover, Lin, Officer, and Zou (2011) find that D\&O insurance aggravates the agency problems in acquisition decisions, which negatively affects acquisition outcomes.
} 
reflects the exposure of the lending banks to moral hazard on the part of borrowers (which is exacerbated by the provision of D\&O insurance coverage). ${ }^{15}$

Next we examine whether the relation between D\&O insurance coverage and loan spreads is weakened by monitoring mechanisms that curb the agency costs induced by D\&O insurance coverage and reduce the monitoring costs to lenders. We focus on three monitoring mechanisms: the number of analysts who follow the borrower, the existence of a blockholder (an indicator that equals one if at least one blockholder owns more than $10 \%$ of the company's shares), and the existence of prior lending relation between the borrower and the lead bank of the syndicated loan (an indicator that equals one for the existence of such relation over the previous five years prior to the loan origination). We expect these mechanisms to help lower the information asymmetry between the borrower and the lending bank(s), reducing the potential for opportunistic behavior by the directors and officers of the borrowing firm and, thereby, lowering the expected credit risk facing the lender.

Panel D of Table 5 presents the results from split-sample regressions based on the number of analysts following the borrower. The coefficient on the insurance coverage ratio variable in the group with less than the median number of analysts is 2.04 (significant at the 0.01 level). In contrast, the coefficient is 0.05 and insignificant in the group with analyst following greater than or equal to the median. Panels E and F report results from similar split-sample analyses based on the presence of a blockholder in the borrowing firm and the existence of a prior lending relation with the lead bank. In both cases, the group with weaker monitoring (no blockholder, no prior relation) has a much larger coefficient on the insurance coverage ratio than the other group, and the difference between the coefficients is statistically significant at the 0.05 level. Overall, these results demonstrate that the effect of D\&O insurance coverage on the cost of

\footnotetext{
${ }^{15}$ In untabulated results, we also split the sample by whether loans have collateral or not. We find that for loans with collateral the regression coefficient on the insurance coverage ratio is 2.3 (significant at the 0.01 level). The regression coefficient is 7.1 for loans without collateral, albeit insignificant. Thus, while the magnitude of the effect goes in the same direction as the tabulated differences, the result lacks statistical power. This might be caused by the high proportion of missing values for the collateral variable, which significantly reduces the sample size.
} 
bank loans is much less pronounced for firms with extensive monitoring by outsiders, again consistent with the idea that $\mathrm{D} \& \mathrm{O}$ insurance exacerbates moral hazard or information asymmetry problems.

\subsection{Endogeneity}

Potential endogeneity is a source of concern for many corporate finance studies. Relative to other studies in the literature, it could be less of a concern in this setting because loan spreads are largely set by firms' creditors or by competitive forces in credit markets. Moreover, we have taken steps to alleviate concerns arising from reverse-causality (by lagging the independent variables) and omitted variables (by using an extensive set of controls, including common proxies for credit risk).

As pointed out in Rajan and Zingales (1998), one way to overcome endogeneity concerns is to focus on detailed theoretical mechanisms through which independent variables affect the dependent variable. The evidence on moderating factors discussed above could, therefore, be viewed as "the 'smoking gun' in the debate about causality" (Rajan and Zingales, 1998, p. 560) as it shows not only whether but how D\&O insurance coverage affects loan spreads: when outside monitoring is weak or when the lead lender is relatively unfamiliar with the borrower. Our consistent results from the split-sample tests of factors that affect the link between D\&O insurance coverage and the cost of bank debt (Table 5), therefore, help reduce the concern about endogeneity in this setting. Despite the detailed moderating factors illustrated in Table 5, however, some unobserved firm-specific characteristics still could affect both D\&O insurance coverage and the cost of debt. Although it is difficult to completely rule out concerns about endogeneity, below we address this issue in two ways. ${ }^{16}$

\footnotetext{
${ }^{16}$ Another way to deal with the endogeneity issue is to examine loan spread changes around the initiation and discontinuation of D\&O insurance coverage. However, insurance entry and exit are rare, presumably because our sample contains large firms. In addition, when there is insurance entry and exit in the firm-year insurance data, a firm might not necessarily have loans in the loan data file. This leaves us too small a sample of insurance entry and exit to produce a meaningful analysis. We adopt an instrumental variable estimation as an additional robustness check but relegate it to the end of the paper.
} 
One way to assess whether the positive relation between D\&O insurance coverage and loan spreads that we observe is driven by endogeneity is to examine the relation in the context of an exogenous event that changes the demand for protection against litigation. Specifically, we examine the enactment of Ontario Bill 198, legislation that expands civil liability for companies whose securities trade in Ontario (including firms on the Toronto Stock Exchange). Ontario Bill 198 expands the list of acts for which firms can be liable to private securities litigation to include liability for misrepresentations in continuous disclosure. The bill became effective on December 31, 2005 (Pritchard and Sarra, 2010).

Ontario Bill 198 substantially increases the potential litigation costs from (malicious) incomplete or misleading disclosures and, therefore, increases the importance of D\&O insurance as a shield from liability for directors and officers. This legislation increases the effective cost of moral hazard for firms with low (or no) D\&O coverage. As a consequence, relative to firms that choose to have low (or no) coverage, firms that elect to have high D\&O coverage (and, therefore, enjoy greater effective protection) send stronger signals to creditors about their potential for executive misbehavior driven by moral hazard [because off-equilibrium behavior is so much costlier for firms with low (or no) D\&O coverage]. Assuming that creditors price this moral hazard, we should expect the effect of D\&O insurance coverage on loan spreads to be more pronounced after Ontario Bill 198 becomes effective (i.e., from 2006 onward). We test this contention by including an indicator for the liability expansion event (equals one for observations from 2006 onward and zero otherwise) in our loan spread models. We also interact this event indicator with the $\mathrm{D \& O}$ insurance coverage ratio and expect the interaction term to have a positive coefficient.

Panel A of Table 6 reports the results. As expected, the interaction term has a positive and significant coefficient, suggesting that Ontario Bill 198 exacerbates the effect of D\&O coverage on loan spreads. In other words, lenders appear to care much more about the loanpricing (moral hazard) implications of D\&O insurance coverage after Ontario Bill 198 becomes effective than they did before. The coefficient on the liability expansion event indicator per se is 
insignificant, which suggests that after the implementation of Ontario Bill 198, firms that carry no D\&O insurance are not charged higher loan spreads. This is consistent with the argument that D\&O insurance coverage could induce unintended moral hazard, as lenders appear to recognize that low (or no) coverage firms are much less likely to engage in opportunistic behavior once such behavior has become much more costly.

\section{[Insert Table 6 near here]}

Second, we run a change model that regresses the change in loan spread on the change in the independent variables. Change regressions have a unique value in this setting, as we can observe lender reactions (increased or decreased loan spreads) to firm-specific changes in D\&O coverage. Conversely, level regressions suffer from potential bias arising from the existence of unobserved time-invariant firm specific variables (e.g., corporate culture or management style). We limit the sample to firms with multiple loan-years and keep only the largest loan facility per borrower per year when a firm has more than one loan in a year (e.g., see Hertzel and Officer, 2012). ${ }^{17}$ This considerably reduces the sample size in the change regression reported in Panel B of Table 6.

The key independent variable is the change in $\mathrm{D} \& \mathrm{O}$ insurance coverage ratio ( $\Delta$ Insurance coverage ratio). It is important to define this variable carefully. Because the denominator is the market value of the firm's equity, if this variable were defined as literally the change in the ratio, then it is possible that the $\Delta$ Insurance coverage ratio variable would be mainly driven by changes in the denominator. To account for this possibility, we define $\Delta$ Insurance coverage ratio as the change in the dollar amount of $\mathrm{D} \& \mathrm{O}$ insurance coverage scaled by the average market value of equity at the beginning and end of the change measurement

\footnotetext{
${ }^{17}$ Consecutive loans to the same borrower could be several years apart (e.g., if the borrower does not take out one loan per year in our overall sample). This is not common in our data and happens approximately $20 \%$ of the time in Panel B in Table 6. For the observations with multi-year changes in spreads, all other independent variables in the regression are measured with the same change frequency.
} 
period (which in $80 \%$ of the cases is one year). This ensures that $\Delta$ Insurance coverage ratio is equal to zero unless the firm changes its (dollar) D\&O insurance coverage limit.

All other independent variables are defined in first-differences. The only variable worth specifically describing is $\Delta$ Credit rating. To control for credit rating changes, we follow Lin, Ma, Malatasta, and Xuan (2011) and use an ordinal coding of credit ratings: $1=$ AAA, 2 = AA, $3=\mathrm{A}, 4=\mathrm{BBB}, 5=\mathrm{BB}, 6=\mathrm{B}$ or worse, and $7=$ no rating. We then take the differences in credit ratings between the years of consecutive loans to the same borrower.

Following Graham, Li, and Qiu (2008), we estimate a median regression of the change in loan spread on the change in insurance coverage. Graham, Li, and Qiu (2008) use median regressions because they are more robust to the effect of outliers. This is important given our sample size. The results from the change regression are in Panel B of Table 6 and are consistent with the levels regressions reported earlier in this paper. Specifically, loan spreads are higher on the firm's next loan if the firm's D\&O insurance coverage limit has increased since the origination of their prior loan. This is consistent with the notion that lenders perceive $\mathrm{D} \& \mathrm{O}$ insurance coverage as increasing (moral hazard) risk or information asymmetry. These results lead us to argue that the positive relation between D\&O insurance coverage and loan spreads is unlikely to be driven by endogeneity.

We provide further robustness tests on this issue at the end of the paper. Specifically, we conduct an extensive set of additional tests for the relation between D\&O insurance coverage and loans spreads, including specifications controlling for a normal (or predicted) amount of D\&O coverage, specifications controlling for the price paid for D\&O insurance, instrumental variables models, and regressions using bond (instead of loan) spreads. These tests are discussed in Section 7.

\section{Economic mechanisms: firm risk taking and financial restatements}

Our evidence suggests that firms with greater D\&O insurance coverage tend to have higher loan spreads. In this section, we seek to understand the economic mechanisms through 
which D\&O insurance coverage could affect the cost of loans. As widely discussed in the literature, information asymmetry and excessive risk taking are important concerns of creditors. ${ }^{18}$ We explore two possibilities: (1) whether directors and officers protected by D\&O insurance are more likely to engage in more risk taking; and (2) whether D\&O insurance leads to low-quality financial reporting (potentially as a result of weaker due diligence, reduced vigilance, or outright manipulation of financial statements). These factors directly, and adversely, affect the position of lenders and, as such, could be viable mechanisms by which D\&O insurance coverage influences loan spreads.

\subsection{D\&O insurance coverage and firm risk taking}

The sample used in this analysis contains firms for which we have D\&O insurance data and daily stock return data from Thomson Reuters Datastream. This intersection gives us a sample of 2,891 firm-years. Following the literature (e.g., Coles, Daniel, and Naveen, 2006), we use two variables to measure firm risk. Total risk is defined as the natural logarithm of the annualized variance of daily stock returns (in percentage) over the fiscal year. Idiosyncratic risk is defined as natural logarithm of the annualized variance of the residuals from a market model using the TSE 300 Index return as the market return. We lag the D\&O insurance coverage ratio by one year relative to these firm risk proxies to allow for causality in time.

Before getting into the regression analysis, we first conduct univariate tests to identify the general patterns in the data. We split the sample at the in-sample median of the $\mathrm{D} \& \mathrm{O}$ insurance coverage ratio and compare the mean values of our risk proxies between these two groups. The results are presented in Panel A of Table 7. As can be seen from the table, univariate comparisons show that firms with higher $\mathrm{D} \& \mathrm{O}$ insurance coverage tend to take more risk. We find that firms with an above-median D\&O insurance coverage ratio tend to have significantly

\footnotetext{
${ }^{18}$ For instance, Graham, Li, and Qiu (2008) find a significant and positive effect of financial restatement on bank loan pricing. Lin, Ma, Malatasta, and Xuan (2011) find that credit risk and information opacity are associated with a significantly higher cost of borrowing.
} 
higher total and idiosyncratic risk, on average, than do firms with below-median coverage, and the differences are statistically significant at the 0.01 level. These univariate tests provide evidence that is consistent with our result on loan spreads. Firms with high D\&O insurance coverage seem to take more risk, and this is reflected in the higher cost of borrowing.

[Insert Table 7 near here]

We conduct regression analyses with Total risk and Idiosyncratic risk as dependent variables. The specifications control for firm characteristics such as size, market-to-book ratio, leverage, research and development $(\mathrm{R} \& \mathrm{D})$ spending, and capital expenditure. Moreover, we control for risk-taking incentives generated by executive compensation. As explained in the literature (e.g., Jensen and Meckling, 1976; and Guay, 1999), both the slope and the convexity of the relation between the stock price and CEO wealth affect managerial risk taking incentives. We, therefore, control for delta (sensitivity of CEO wealth to changes in stock price) and vega (sensitivity of CEO wealth to changes in stock price volatility) along with managerial cash compensation (salary, bonus, and other annual compensation) in our regressions. Specifically, delta is defined as the change in the value of a CEO's wealth (i.e. stock options and stockholdings) for a $\$ 1$ increase in the stock price. Vega is defined as the change in the value of a CEO's wealth (i.e. stock options and stockholdings) for a 1\% change in stock return volatility. All measures of delta and vega are expressed in thousands of dollars, and all control variables are lagged by one year relative to the risk measures.

The regressions in Columns 1-2 of Table 7, Panel B use Total risk as the dependent variable, and the results based on Idiosyncratic risk are presented in Columns 4-5. In Columns 2 and 5, we also include firm fixed effects to mitigate the omitted variable bias. As can be seen from the table, the regression results confirm the findings in the univariate tests. The D\&O insurance coverage ratio is significantly positively associated with both total and idiosyncratic risk in all specifications in Table 7 . In other words, our evidence does suggest that firms with 
high levels of D\&O insurance coverage take on more risks, consistent with their lenders charging such firms higher borrowing spreads.

In terms of the control variables, we find that, consistent with Coles, Daniel, and Naveen (2006), larger firms, firms with higher market-to-book ratios, and firms with low R\&D spending exhibit lower risk (however measured). Also consistent with Coles, Daniel, and Naveen (2006), the leverage ratio and CEO vega are positively correlated with firm risk measures (though their coefficients are not significant in models with firm fixed effects).

One could argue that a positive relation between (lagged) D\&O insurance coverage and future risk taking is an artifact of the endogeneity of D\&O insurance. While finding a perfect instrument variable is extremely difficult, we follow the recent literature (Adams, Lin, and Zou, 2011; and Lin, Officer, and Zou, 2011) and use the industry median insurance coverage ratio based on firms in the same year and with the same cross-listing status as an instrument for the firm's D\&O coverage ratio. We define industries using the Fama and French 30 industry groupings. The following considerations drive our choice of this instrumental variable. ${ }^{19}$ First, firms in the same region and same industry need to compete for a limited pool of managerial talents in the local labor market, and so a firm's executive compensation package (including D\&O insurance coverage) is likely to follow the compensation practice of competitors (Adams, Lin, and Zou, 2011). Second, firms in the same industry face similar business risks and, therefore, shareholder litigation could exhibit industry patterns (Hertzel and Officer, 2012; and Lin, Officer, and Zou, 2011). Thus, a firm's D\&O insurance policy might be shaped by the trend in the industry to manage business and litigation risks.

The IV estimation results reported in Columns 3 and 6 of Panel B in Table 7 are qualitatively unchanged. Furthermore, we estimate a regression of the change in risk on the (lagged) change in insurance coverage ratio to minimize the possibility that omitted variables drive our results. The results from median regressions reported in Panel $\mathrm{C}$ of Table 7 show that

\footnotetext{
${ }^{19}$ We contend that this instrument is a reasonable one that has been used in the prior literature and has explanatory power for a firm’s D\&O insurance choices.
} 
an increase in the D\&O insurance coverage ratio increases a firm's future total and idiosyncratic risk. These results provide support for the argument that D\&O insurance induces unintended moral hazard by enabling the insured firm to take on more risk.

\subsection{D\&O insurance coverage and financial restatements}

To examine whether D\&O insurance leads to low-quality financial reporting (i.e., information asymmetry), we construct financial restatement indicator variables. We first download the annual report for each firm-year in our D\&O insurance sample from the SEDAR database. We set the restatement variables to missing for a firm-year when there is no usable annual report. We then search in the downloaded annual reports for the keyword "restat.” If the annual report for a firm-year has no reference of the keyword, the firm-year's restatement indicator is set equal to zero. When a keyword is found, we read the surrounding text to code the restatement variables. Restatements arising from accounting standard changes and other normal restatements required for the comparability of financial statements (e.g., due to discontinued operations, mergers and acquisitions) are not regarded as a restatement (i.e., the restatement indicator is set to zero). Otherwise, we follow Hennes, Leone, and Miller (2008) to determine whether the restatement is intentional or unintentional (i.e., due to a careless error). Hennes, Leone, and Miller (2008) argue that it is important to distinguish restatements arising from intentional manipulation versus unintentional mistakes. In our sample, this process results in 3,208 usable observations, each of which is a firm-year with non-missing D\&O insurance coverage and restatement indicator data.

We first examine univariate differences between the restatement indicator variables in Panel A of Table 8. Specifically, we split the sample using the in-sample median of the D\&O insurance coverage ratio and compare the mean values of our restatement indicator variables between these two groups. As can be seen in Panel A, these simple comparisons are consistent with the notion that low-quality financial reporting is one channel through which $\mathrm{D} \& \mathrm{O}$ insurance

coverage adversely affects the position of creditors (and hence increases the cost of borrowing). 
Specifically, we find that firms with high D\&O coverage tend to have a significantly higher incidence of earnings restatement, on average, than do firms with low D\&O coverage. For instance, on average 8.8\% of firm-years have an earnings restatement for firms with high D\&O coverage and only $2.2 \%$ of firm-years for firms with low D\&O insurance coverage are affected by a restatement. More troubling, this difference appears to be driven by differences in intentional restatements (last row of Panel A). The differences are statistically significant at the 0.01 level.

[Insert Table 8 near here]

To explore this issue more rigorously, we examine the effect of D\&O insurance coverage on the incidence of earnings restatement using fixed effects linear probability models and probit regressions, both controlling for various firm characteristics (size, market-to-book ratio, leverage, profitability, stock return over prior year, and big-five auditor indicator) and corporate governance variables (independent board member ratio, CEO duality, dual-class share structure, and the presence of a blockholder). ${ }^{20}$ The empirical results are presented in Panel B of Table 8. Marginal effects derived from the probit coefficients are reported in Columns 2 and 4. The D\&O insurance coverage ratio and all control variables are lagged by one year relative to the restatement indicator variables.

The regression results confirm our findings in the univariate tests. Specifically, we find that the $\mathrm{D} \& \mathrm{O}$ insurance coverage ratio is positively associated with the incidence of earnings restatement and the incidence of intentional earnings restatement, as indicated by the positive and statistically significant coefficients across all model specifications.

\footnotetext{
${ }^{20}$ The advantage of a linear probability model with fixed effects is that it enables us to control for time-invariant omitted variables, but it does not take account of the binary nature of the dependent variable. In contrast, a discrete choice model such as probit reflects the binary nature of the dependent variable but is not well-suited to handling firm fixed effects (e.g., Katz, 2001). For robustness, we estimate both models.
} 
One could argue that a positive relation between (lagged) D\&O insurance coverage and future financial restatements is an artifact of the endogeneity of D\&O insurance. In Columns 3 and 6 of Panel B in Table 8, we report the results from the IV estimation that uses the industry median insurance coverage ratio in the same year as the instrument for the potentially endogenous regressor. We find that the results are robust. Finally, we regress the restatement indicators on the change in insurance coverage ratio to minimize the possibility that omitted variables drive our results. The results from the probit regressions reported in Panel C of Table 8 show that an increase in the $\mathrm{D} \& \mathrm{O}$ insurance coverage ratio increases the probability of subsequent (intentional) financial restatements.

Overall, these results bolster our previous findings and help explain the link between D\&O insurance coverage and loan spreads. Higher D\&O insurance coverage appears to be associated with greater risk taking (Table 7) and lower-quality financial reporting (Table 8), and both attributes adversely affect the position of creditors.

\section{Can the purchase of $\mathrm{D} \& \mathrm{O}$ insurance be beneficial for shareholders?}

Our analysis thus far points to a cost of having D\&O insurance coverage: higher costs of borrowing. This finding is consistent with prior studies arguing that $\mathrm{D} \& \mathrm{O}$ insurance purchase is associated with managerial opportunism (e.g., see Chalmers, Dann, and Harford, 2002; Chung and Wynn, 2008; Wynn, 2008; and Lin, Officer, and Zou, 2011). However, because their financial and human capital is concentrated within the firm, managers and directors are likely to take a sub-optimal amount of risk in corporate decisions (from the perspective of shareholders). Because D\&O insurance coverage protects directors' personal wealth from litigation in the case of lower than expected payoffs from a risky project, D\&O insurance could help companies attract and retain able risk averse outsiders to serve in the firm and the protection of $\mathrm{D} \& \mathrm{O}$ insurance may encourage directors and officers to make risky investments that would be otherwise passed up (Bhagat, Brickley, and Coles, 1987; and Core, 1997). ${ }^{21}$ Potentially

\footnotetext{
${ }^{21}$ We thank an anonymous referee for this suggestion.
} 
consistent with this, Bhagat, Brickley, and Coles (1987) find a positive and marginally significant market reaction to D\&O insurance purchases for 11 New York-based firms.

If $\mathrm{D} \& \mathrm{O}$ insurance can help companies attract and retain able risk-averse outsiders to serve in the firm and enable them to make risky investments that are beneficial to shareholders, it is likely that this benefit is ultimately reflected in the value of a firm's investment. Furthermore, this effect should be more pronounced in firms with good corporate governance, because good governance helps shareholders monitor managerial investment decisions and align corporate investments with shareholders’ interests.

In the spirit of Faulkendar and Wang (2006) and Masulis, Wang, and Xie (2009), we examine the marginal value of large increases in capital expenditures. As in Masulis, Wang, and Xie (2009), we restrict our sample to firm-years in which there is at least 5\% growth in capital expenditure relative to the prior fiscal year. We then regress fiscal-year firm-level excess stock returns on capital expenditure changes, D\&O insurance coverage and their interaction, and other controls for financing, investment, earnings, and dividends. Excess returns are the difference between a firm's fiscal year return and the value-weighted return to the firm's Fama and French 30 industry portfolio over the same period.

To examine whether the effect of D\&O insurance on the marginal value of capital expenditure varies with the quality of corporate governance, we use the proportion of independent directors on the board as a proxy for the strength of internal corporate governance and product market competition as a proxy for the strength of external governance (see Giroud and Muller, 2011). We use two measures for product market competition: (1) a HerfindahlHirschman Index (HHI) that is constructed for each of the Fama and French 30 industries and each fiscal year using our sample and other Canadian listed firms; and (2) a firm’s market share. A high HHI or market share implies weak external governance.

The results from the marginal value of large capital expenditure increase are reported in Table 9. In Columns 1 and 2, the sample is split according to whether a firm's proportion of independent directors is lower than the sample median or not. Of interest are the positive and 
weakly significant coefficient of the interaction between the D\&O insurance coverage ratio and the change in capital expenditures in the high board independence group and the negative and statistically significant coefficient on the same interaction in the low board independence group. That is, the provision of $\mathrm{D} \& \mathrm{O}$ insurance appears to marginally improve the value of investment when there is effective monitoring provided by a high level of board independence. In contrast, D\&O insurance tends to decrease shareholder returns when board independence is low and the monitoring of independent directors is lacking.

\section{[Insert Table 9 near here]}

The coefficient on the insurance coverage ratio per se is negative and statistically significant, and in untabulated results based on the pooled sample we confirm that the insurance coverage ratio also has a negative and statistically significant coefficient in a model without the interaction term. This suggests that firms with high levels of D\&O insurance on average exhibit lower excess returns, which is in the spirit of the managerial opportunism and unintended moral hazard effect of D\&O insurance as shown in prior studies (e.g., Chalmers, Dann, and Harford, 2002; Chung and Wynn, 2008, Wynn, 2008; and Lin, Officer, and Zou, 2011).

In Columns 3 and 4, we follow Akdogu and MacKay (2008) and split the sample based on whether a firm operates in an industry that has high product market competition (i.e., HHI < 0.1) or not. The results show that D\&O insurance appears to improve the marginal value of investment for firms operating in competitive product markets, possibly because competitive environments leave less room for managerial slacks and agency problems. The effect of D\&O insurance on the marginal value of capital expenditure is negative but insignificant when market competition is low. In Columns 5 and 6, the sample is split based on whether a firm's market share is lower than the median market share in its Fama and French 30 industry in the fiscal year. Firms with a high market share have high market power and their managers could be more likely to enjoy the quiet life. The results suggest that the effect of $\mathrm{D} \& \mathrm{O}$ insurance on the marginal value of capital expenditure is negative when a firm's market share is higher than the industry 
median market share.

Taken together, these results provide moderate evidence that while firms with a high level of D\&O insurance on average exhibit lower excess returns, strong monitoring afforded by independent directors and competition in product markets seems to lead to increased investment efficiency, which can be beneficial to shareholders.

\section{Other robustness tests}

This section presents the results from several other robustness tests of the effect of D\&O insurance coverage on loan spreads, as well as corroborating evidence on the effect of D\&O insurance coverage on the cost of debt using a bond sample.

\subsection{Excess coverage}

Our loan spread results in Tables 4-6 are obtained from regressions using the raw insurance coverage ratio as the independent variable of interest. To provide more direct evidence on whether abnormally high insurance coverage increases loan spreads, we replace the raw coverage ratio with an estimated excess coverage ratio. Excess insurance coverage is defined as the residual coverage amount (in dollars) scaled by the average market value of equity. The residual coverage amount is obtained from an insurance coverage prediction model similar to Core (1997), in which the dependent variable is the logged policy limit and the explanatory variables include logged market value of equity, leverage, cash holdings, profitability, Herfindahl Index, and indicator variables for US listing, board independence, and having a prior divestiture. We also include industry and year fixed effects in the insurance coverage prediction model. In untabulated results, we find that firms that are larger, that have equity (jointly) listed in the US, and that have more independent directors choose to have high policy limits. These results are consistent with Core (1997).

Column 1 in Table 10 reports the results from regressing loan spreads on excess coverage ratios (the residuals from the regression described above, scaled by the average market value of equity). While the magnitude of the coefficient on the excess coverage ratio in Column 1 is 
smaller than the coefficients on the raw coverage ratio (Table 4), it is positive and significant at the 0.01 level. $^{22}$

\section{[Insert Table 10 near here]}

\subsection{Inclusion of $D \& O$ insurance premiums as an additional control}

Core (2000) finds that the premium charged by D\&O insurers appears to reflect litigation risk and the quality of corporate governance. Chalmers, Dann, and Harford (2002) argue that opportunistic managers with private information could seek excessive coverage and are willing to pay an abnormally high premium for such coverage. Baker and Griffith (2007) find that insurance underwriters focus on corporate governance in assessing risk and D\&O insurers are sophisticated in pricing, as they look not only at formal governance structures but also at "deep" governance variables (e.g., corporate culture). Boyer and Stern (2012) report that D\&O insurers charge a higher premium to income trusts than to common equity firms. These studies collectively suggest that the insurance price (premium) charged by D\&O insurers can proxy for litigation risk and corporate governance, and an abnormally high insurance price should be another predictor in our loan spread models if spreads are reacting to moral hazard or information asymmetry. ${ }^{23}$

In Column 2 of Table 10 we include in the loan spread model a variable called Insurance price, defined as the $\mathrm{D} \& \mathrm{O}$ insurance premium scaled by the personal (Side-A) policy coverage limit. Because the insurance price is missing for firms without insurance, the sample size drops by around 20\%. The results in Column 2 show that the coefficient on the insurance coverage ratio continues to be statistically significant and positively related to loan spreads, suggesting

\footnotetext{
${ }^{22}$ If we include internal governance variables (i.e., blockholder, CEO duality, and dual-class indicators) in our firststage insurance coverage prediction models, none of these governance variables loads significantly and the qualitative effect of excess coverage on loan spreads is unaffected. Chalmers, Dann, and Harford (2002) also find that the blockholder variable is insignificant in their insurance coverage model.

${ }^{23}$ We thank anonymous referee for providing us with this valuable insight.
} 
that the relation between $\mathrm{D} \& \mathrm{O}$ insurance and loan spreads is robust to the control for insurance price. Also, Insurance price per se has a positive and statistically significant coefficient in Column 2, consistent with the Core (2000) argument that D\&O insurance premiums reflect the quality of corporate governance and potential for litigation risk and appear to be related to the same risk factors priced into bank loans.

Next, to provide more direct evidence on abnormally high insurance premiums increasing loan spreads, in Column 3 we replace the insurance price variable with an estimated excess insurance premium measure. We follow the approach adopted in Chalmers, Dann, and Harford (2002) and Core (2000) to model D\&O insurance premiums. Excess insurance price is the residual from a model that regresses D\&O insurance premiums on excess coverage and all variables used in the excess coverage model (described above) scaled by the amount of coverage. Column 3 shows that the relation between loan spreads and excess D\&O insurance coverage remains robust to the inclusion of estimates of the abnormal price paid to purchase such insurance. In summary, the relation we demonstrate between loan spreads and the amount of D\&O insurance coverage appears to be qualitatively unaffected by controlling for insurance premiums paid by firms (either raw or excess) as an additional control for governance or litigation risk.

\subsection{Macroeconomic uncertainty}

Aggregate uncertainty is high in recessions, and loan spreads could widen for macro reasons. Because risk aversion in the economy is also high during recessions, directors and officers may demand more D\&O insurance coverage. This could lead to a spurious positive relation between D\&O insurance coverage and loan spreads. We check whether this possibility drives our results by eliminating loans originated in recession years from our sample.

According to the National Bureau of Economic Research (NBER), 2001 is a recession

year due to the collapse of the dot-com bubble and the September 11th attacks, which led to a dramatic fall in business outlays and investments. The subprime mortgage crisis caused the most 
recent recession in 2008. The results reported in Column 4 of Table 10 show that the insurance coverage ratio still commands a positive and significant coefficient even when loans originated in these years (2001 and 2008) are excluded from the regression.

As another attempt to examine whether our results are driven by macroeconomic uncertainty, we add controls for economy-wide credit spreads. We define economy-wide credit spreads as the yield on (US) AAA-rated corporate bonds minus three-month LIBOR measured at the loan origination date. ${ }^{24}$ When there is greater uncertainty in the market, creditors require a higher risk premium and economy-wide credit spreads widen (Campello, Lin, Ma, and Zou, 2011). Regression results with the economy-wide credit spread as a control variable are reported in Column 5 of Table 10. As expected, firm-specific loan spreads are significantly positively associated with economy-wide credit spreads. However, the coefficient on D\&O insurance coverage is qualitatively unaffected. Hence, our result does not seem to be driven by the spurious relation between D\&O insurance and loan spreads arising from macroeconomic uncertainty.

\subsection{Additional tests for endogeneity}

In Table 6, we use a change regression and an estimation exploiting an exogenous regulatory change to address the endogeneity issue of D\&O insurance coverage in the loan spread model. In this subsection, we provide two more checks. First, we attempt to minimize the omitted variable bias by adding firm fixed effects (in place of industry fixed effects). The inclusion of firm fixed effects helps eliminate time-invariant unobserved characteristics that might inadvertently induce the relations we observe. ${ }^{25}$ The results reported in Column 6 of Table

\footnotetext{
${ }^{24}$ AAA-rated corporate bond yields are for US bonds (from the Federal Reserve Board's website) and three-month LIBOR data are obtained from Bloomberg. We do not have access to AAA-rated corporate bond yields for Canada. Given the geographical proximity and the close economic integration between the US and Canada, however, we feel that the US credit spread reasonably reflects macroeconomic uncertainty in Canada. We thank an anonymous referee for suggesting this test.

${ }^{25}$ Some time-invariant (firm characteristic) control variables are dropped from the regressions when firm fixed effects are added.
} 
10 show that the insurance coverage ratio still has a positive and significant effect on loan spreads even after the addition of firm fixed effects to the model, with the magnitude of the coefficients being comparable to those reported in prior tables.

Second, we report results from the IV estimation that uses the industry median insurance coverage ratio based on firms in the same year and with the same cross-listing status as an instrument for the firm's D\&O coverage ratio. The first-stage IV regression is a Tobit regression of the D\&O insurance coverage ratio in a firm-year on the instrument and all the control variables from Column 4 in Table 10. The F-statistics for the first-stage regression (reported near the bottom of Column 7 in Table 10) indicate that the coefficient on the excluded instrument is significantly different from zero at the 0.01 level. We also calculate Shea's (1997) partial $R^{2}$ from the first-stage regression. The $R^{2}$ exceeds the suggested (rule of thumb) hurdle of $10 \%$ by a large margin. These tests suggest that our instrument is relevant in explaining the variation in the potentially endogenous regressor ( $\mathrm{D} \& \mathrm{O}$ insurance coverage). For brevity, we present only the second-stage regression results in Column 7 of Table 10. As can be seen from the table, the coefficient on the instrumented insurance coverage ratio is still robust.

\subsection{Bond spreads}

We check the robustness of our results concerning the relation between D\&O insurance coverage and loan spreads using bond data, as the same logic underpinning the relation between D\&O insurance coverage and loan spreads should also apply to bonds.

We obtain bond issuance data for Canadian issuers primarily from Bloomberg and supplement it by data from the Mergent Fixed Income Securities Database (FISD). It is worth noting that the Bloomberg bond data do not contain the at-issuance yield to maturity, which we calculate using the bond's issue price, maturity, and other parameters. We then subtract from a bond's at-issuance yield to maturity the yield on zero-coupon government bonds with the same time to maturity (obtained from the Bank of Canada website) on the bond issuance day to derive the at-issuance bond spread. The bond data obtained from the FISD already contain bond spreads, 
although some bonds have missing spreads. We exclude financial firms from analysis and exclude bonds with missing or negative spreads. Finally, we end up with 328 bonds with nonmissing basic firm and bond characteristics for our analysis.

The results from regressing bond spreads (in percentage points) on the $\mathrm{D} \& \mathrm{O}$ insurance coverage ratio controlling for firm and bond characteristics are reported in Column 1 of Table 11. In Column 2, we add governance variables and the sample is reduced further. The results in Table 11 suggest that higher D\&O insurance coverage ratios are associated with higher (atissuance) bond spreads. Using the point estimate in Column 2, a one-standard-deviation increase in the $\mathrm{D} \& \mathrm{O}$ insurance coverage ratio increases the bond spread by about 35 basis points. Therefore, we find qualitatively similar results using bond data as we found with our sample of corporate loans. The larger marginal effect of D\&O insurance coverage on bond spreads compared with loan spreads is consistent with the fact that banks, as providers of private debt financing, have more control over borrowers and can monitor them more closely than public bondholders can. We note, however, that the small sample sizes and the combination of two different data sources make this conclusion somewhat tenuous.

[Insert Table 11 near here]

\section{Conclusion}

Using a unique data set of corporate purchases of D\&O insurance by Canadian firms, we examine whether D\&O insurance coverage affects the cost of borrowing. We find that higher levels of D\&O insurance coverage are associated with higher loan spreads, suggesting that lenders perceive D\&O insurance coverage as impairing their ability to monitor or control the borrower. Further analyses show that greater risk taking and lower-quality financial reporting (resulting in a higher probability of financial restatement) could explain why lenders appear to penalize firms that carry higher levels of D\&O insurance coverage. Moreover, these concerns appear to vary according to different loan terms and be mitigated by more intense outside 
monitoring or when lenders are more familiar with their borrowers, as one might expect if the observed relation is driven by information asymmetry or moral hazard. The result that D\&O insurance coverage increases loan spreads is robust to various endogeneity checks.

Taken together, our results are consistent with the argument that $\mathrm{D} \& \mathrm{O}$ insurance coverage could generate incentives that are harmful to lenders, who price-protect themselves by charging higher loan spreads. Our study provides the first evidence suggesting how creditors view the prevalent use of D\&O insurance. It also identifies a new factor that is taken into account by creditors in loan contracting and pinpoints a channel through which D\&O insurance could affect firm value.

Finally, we also explore if providing D\&O insurance for directors and officers can be beneficial to shareholders despite the penalty imposed by creditors. While the effect of D\&O insurance coverage on firm performance is on average negative, we find some evidence that D\&O insurance appears to improve the marginal value of large increases in capital expenditures when there is strong monitoring afforded by independent directors or product market competition. This suggests that the provision of $\mathrm{D} \& \mathrm{O}$ insurance could have different implications for some stakeholders under certain circumstances. 


\section{References}

Adams, M., Lin, C., Zou, H., 2011. Chief executive officer incentives, monitoring, and corporate risk management: evidence from insurance use. Journal of Risk and Insurance 78, 551-582.

Akdogu, E., MacKay, P., 2008. Investment and competition. Journal of Financial and Quantitative Analysis 43, 299-330.

Amihud, Y., Lev, B., 1981. Risk reduction as a managerial motive for conglomerate mergers. Bell Journal of Economics 12, 605-617.

Baker, T., Griffith, S., 2007. Predicting corporate governance risk: evidence from the directors’ and officers’ liability insurance market. University of Chicago Law Review 74, 487-544.

Baker, T., Griffith, S., 2010. Ensuring Corporate Misconduct: How Liability Insurance Undermines Shareholder Litigation. University of Chicago Press, Chicago IL.

Bertrand, M., Mullainathan, S., 2003. Enjoying the quiet life? Corporate governance and managerial preferences. Journal of Political Economy 111, 1043-1075.

Bhagat, S., Brickley, J., Coles, J., 1987. Management identification and liability insurance: the effect on stockholder Wealth. Journal of Risk and Insurance 54, 721-736.

Boyer, M., 2005. Directors' and officers' insurance and shareholder protection. Unpublished working paper. HEC-Montreal University, Montreal Quebec, Canada.

Boyer, M., Stern, L., 2012. Is Corporate governance risk valued? Evidence from directors' and officers’ insurance. Journal of Corporate Finance 18, 349-372.

Bradley, M., Chen, D., 2011. Corporate governance and the cost of debt: evidence from director limited liability and indemnification provisions. Journal of Corporate Finance 17, 83-107.

Campello, M., Lin, C., Ma, Y., Zou, H., 2011. The real and financial implications of corporate hedging. Journal of Finance 66, 1615-1647.

Carey, M., Nini, G., 2007. Is the corporate loan market globally integrated? A pricing puzzle. Journal of Finance 62, 2969-3001. 
Chalmers, J., Dann, L., Harford, J., 2002. Managerial opportunism? Evidence from directors' and officers' insurance purchases. Journal of Finance 57, 609-636.

Cheffins, B., Black, B., 2006. Outside director liability across countries. Texas Law Review 84, 1385-1480.

Chung, H., Wynn, J., 2008. Managerial legal liability coverage and earnings conservatism. Journal of Accounting and Economics 46, 135-153.

Coles, J., Daniel, N., Naveen, L., 2006. Managerial incentives and risk-taking. Journal of Financial Economics 79, 431-468.

Core, J., 1997. On the corporate demand for directors' and officers' insurance. Journal of Risk and Insurance 64, 63-87.

Core, J., 2000. The directors' and officers' insurance premium: an outside assessment of the quality of corporate governance. Journal of Law, Economics, and Organization 16, 449-477.

Donley, S., Kent, N., 2008. Directors and officers liability in Canada: a review of exposures and coverage available under D\&O policies. Clark Wilson LLP, Vancouver British Columbia, Canada.

Egri, C., Gordon, I., Shapiro, D., 2006. Director and officer liability insurance: analysis of survey results. CIBC Centre for Corporate Governance and Risk Management, Simon Fraser University, Vancouver BC.

Faulkender, M., Wang, R., 2006. Corporate financial policy and the value of cash. Journal of Finance 61, 1957-1990.

Gillan, S., Panasian, C., 2010. Reassessing what matters in corporate governance: evidence from the market for directors' and officers' liability insurance. Unpublished working paper. Texas Tech University, Lubbock TX.

Giroud, X., Muller, G., 2010. Does corporate governance matter in competitive industries? Journal of Financial Economics 95, 312-331. 
Giroud, X., Muller, G., 2011. Corporate governance, product market competition, and equity prices, Journal of Finance 66, 563-600.

Graham, J., Li, S., Qiu, J., 2008. Corporate misreporting and bank loan contracting. Journal of Financial Economics 89, 44-61.

Guay, W., 1999. The sensitivity of CEO wealth to equity risk: an analysis of the magnitude and determinants. Journal of Financial Economics 53, 43-71.

Hennes, K., Leone, A., Miller, B., 2008. The importance of distinguishing errors from irregularities in restatement research: the case of restatements and CEO/CFO turnover. Accounting Review 83, 1487-1519.

Hertzel, M., Officer, M., 2012. Industry contagion in loan spreads. Journal of Financial Economics 103, 493-506.

Hirshleifer, D., Thakor, A., 1992. Managerial conservatism, project choice, and debt. Review of Financial Studies 5, 437-470.

Holderness, C., 1990. Liability insurers as corporate monitors. International Review of Law and Economics 10, 115-129.

Holmstrom, B., Ricart I Costa, J., 1986. Managerial incentives and capital management. Quarterly Journal of Economics 101, 835-860.

Jensen, M., Meckling, W., 1976. Theory of the firm: managerial behavior, agency costs, and ownership structure. Journal of Financial Economics 3, 305-360.

John, K., Litov, L., Yeung, B., 2008. Corporate governance and managerial risk taking: theory and evidence. Journal of Finance 63, 1679-1728.

Katz, E., 2001. Bias in conditional and unconditional fixed effects logit estimation. Political Analysis 9, 379-384.

Lin, C., Ma, Y., Malatesta, P., Xuan, Y., 2011. Ownership structure and the cost of corporate borrowing. Journal of Financial Economics 100, 1-23. 
Lin, C., Officer, M., Zou, H., 2011. Directors’ and officers’ liability insurance and acquisition outcomes. Journal of Financial Economics 102, 507-525.

Lowry, M., Field, L., Shu, S., 2005. Does disclosure deter or trigger litigation? Journal of Accounting and Economics 39, 487-507.

Lowry, M., Shu, S., 2002. Litigation risk and IPO underpricing. Journal of Financial Economics 65, 309-336.

Masulis, R., Wang, C., Xie, F., 2009. Agency problems at dual-class companies. Journal of Finance 64, 1697-1727.

Mayers, D., Smith, C., 1982. On the corporate demand for insurance. Journal of Business 55, 281-296.

Mayers, D., Smith, C., 1990. On the corporate demand for insurance: evidence from the reinsurance market. Journal of Business 63, 19-40.

Moeller, S., Schlingemann, F., Stulz, R., 2004. Firm size and the gains from acquisitions. Journal of Financial Economics 73, 201-228.

Pritchard, A., Sarra, J., 2010. Securities class actions move north: a doctrinal and empirical analysis of securities class actions in Canada. Alberta Law Review 47, 881-926.

Rajan, R., Zingales, L., 1998. Financial dependence and growth. American Economic Review 88, 559-586.

Shea, J., 1997. Instrument relevance in multivariate linear models: a simple measure. Review of Economics and Statistics 79, 348-352.

Shleifer, A., Vishny, R., 1997. A survey of corporate governance. Journal of Finance 52, 737783.

Zou, H., 2010. Hedging affecting firm value via financing and investment: evidence from property insurance use. Financial Management 39, 965-995.

Zou, H., Adams, M.B., 2008. Debt capacity, cost of debt and corporate insurance. Journal of Financial and Quantitative Analysis 43, 433-466. 


\section{Table 1}

Variable definitions

Variable

Definition

Directors' and officers' (D\&O) insurance information

Insurance $(1 / 0)$

Indicator variable equal to one if the firm purchases $\mathrm{D} \& \mathrm{O}$ insurance in the fiscal year and zero otherwise.

Coverage amount

The limit on the personal coverage of D\&O insurance in millions of US dollars.

Insurance coverage ratio

$\Delta$ Insurance coverage ratio

Limit on the personal coverage of the $\mathrm{D} \& \mathrm{O}$ insurance divided by market value of equity at the fiscal year-end.

Change in the dollar amount of personal coverage limit divided by average market value of equity at the beginning and end of the change period.

Moderate coverage indicator (1/0)

Indicator variable equal to one if a firm has D\&O insurance and the insurance coverage ratio is below the median coverage ratio for the sample of firms with insurance and zero otherwise.

High coverage indicator (1/0)

Indicator variable equal to one if a firm has $\mathrm{D} \& \mathrm{O}$ insurance and the insurance coverage ratio is above the median coverage ratio for the sample of firms with insurance and zero otherwise.

Excess insurance coverage

The residual coverage amount (in dollars) scaled by the average market value of equity in the year. The residual coverage amount is obtained from an insurance model in the manner of Core (1997), in which the dependent variable is the logged policy limit and the economic determinants of D\&O insurance include logged market value of equity, leverage, cash holdings, profitability, US listing, board independence, having a prior divestiture or not, Herfindahl Index, and industry and year fixed effects.

Insurance price

The premium of D\&O insurance divided by limit on the personal coverage of D\&O insurance.

Excess insurance price

The residual from the model that regresses insurance premiums on the dollar amount of excess coverage and all variables used in the excess coverage model scaled by the amount of coverage.

Loan characteristics

Loan spread

The all-in-drawn spread over the London Interbank Offered Rate (LIBOR) charged by the bank for the loan facility, in basis points.

$\Delta$ Loan spread

Change in the spread on consecutive loans to the same borrower; sample includes only the largest loan per borrower per year.

Loan size

Loan (facility) amount in millions of US dollars. 
Loan maturity

Performance pricing (1/0)

Loan type indicators $(1 / 0)$

Loan purpose indicators (1/0)

Lending relationship indicator (1/0)

Firm characteristics

Assets

Market-to-book

Profitability

Leverage

Cash flow volatility

Tangibility

Credit rating indicators $(1 / 0)$

Total risk

Idiosyncratic risk

Sales growth

$\mathrm{R} \& \mathrm{D}$

Capex

Stock return over prior year

Big-five auditor (1/0)
The maturity of the loan facility.

Indicator variable equal to one if the loan facility uses performance pricing and zero otherwise.

Indicator variables for loan type (term loan, revolver greater than one year, revolver less than one year, and 364-day facility).

Indicator variables for loan purpose (including corporate purposes, working capital, debt repayment, acquisition, backup line for commercial paper, and others).

Indicator variable equal to one if a borrowing-lending relation exists between the borrower and the lead bank of the current loan over the previous five years prior to the loan origination and zero otherwise.

Book value of total assets in millions of US dollars.

The sum of fiscal year-end market value of equity and book value of liabilities, divided by total assets.

Earnings before interest and taxes divided by total assets.

The sum of long-term debt plus debt in current liabilities, divided by total assets.

Natural logarithm of the standard deviation of annual cash flows from operations over the four fiscal years prior to debt origination, scaled by the total assets excluding cash and cash equivalents.

Net property, plant and equipment divided by total assets.

Indicator variables for each category of Standard and Poor's (S\&P) credit ratings (AAA, AA, A, BBB, BB, B or worse).

Natural logarithm of the annualized variance of daily stock returns (in percentage) over the fiscal year.

Natural logarithm of the annualized variance of the residuals from the market model (the market return is the return to the S\&P/TSX Composite Index).

Natural logarithm of $\left(\right.$ Sales $_{t} /$ Sales $\left._{t-1}\right)$.

Research and development expenditure divided by total assets.

Net capital expenditure divided by total assets.

Stock returns over the previous fiscal year (calculated using compounded daily stock returns) net of the daily compounded return to the S\&P/TSX Composite Index over the same period, measured in percent.

Indicator variable equal to one if the company employed a big-five 
Analyst following

Excess return

$\Delta$ Capex

$\Delta$ Earnings

$\Delta$ Net assets

$\Delta \mathrm{R} \& \mathrm{D}$

$\Delta$ Interest

$\Delta$ Dividends

$\Delta$ Cash

Net financing

Earnings restatement variables Restatement indicator (1/0)

Intentional restatement indicator $(1 / 0)$

Governance variables

Independent directors

Blockholder (1/0) accounting firm as the auditor in a year and zero otherwise.

The number of analysts following the firm in a year.

A firm's compounded daily return in a fiscal year minus the valueweighted return of the corresponding Fama and French 30 industry portfolios return over the fiscal year.

(Capital expenditure $t_{t}$ - capital expenditure t-1 $_{1}$ ) divided by market value of equity at the beginning of the fiscal year.

(Earnings $_{t}$ - earnings $s_{t-1}$ ) divided by market value of equity at the beginning of the fiscal year, where earnings equals income before extraordinary items plus interest expense plus deferred income tax plus investment tax credits.

(Net assets $_{t}$ - net assets N-1 $_{\text {- }}$ ) divided by market value of equity at the beginning of the fiscal year, where net assets equal total assets minus cash and short-term investments.

( $R \& D$ expense $e_{t}-R \& D$ expense $e_{t-1}$ ) divided by market value of equity at the beginning of the fiscal year.

(Interest expense $_{t}$ - interest expense ${ }_{t-1}$ ) divided by market value of equity at the beginning of the fiscal year.

(Common dividends $t_{t}$ - common dividends $s_{t-1}$ ) divided by market value of equity at the beginning of the fiscal year.

(Cash and short-term investments s $_{t}$ - cash and short-term investments $\mathrm{s}_{t-1}$ ) divided by market value of equity at the beginning of the fiscal year.

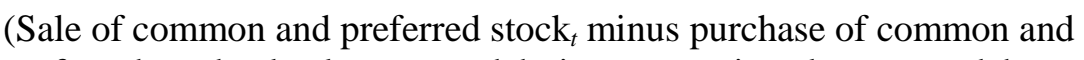
preferred stock $_{t}$ plus long-term debt issuance ${ }_{t}$ minus long-term debt repayment $_{t}$ ) divided by market value of equity at the beginning of the fiscal year.

Indicator variable equal to one if there is an earnings restatement in a fiscal year and zero otherwise. Restatements arising from accounting standard changes and other normal restatements for the comparability of financial statements (e.g., due to discontinued operations, mergers and acquisitions) are not regarded as restatements.

Indicator variable equal to one if the earnings restatement is due to intentional misstatement and zero otherwise. Following Hennes, Leone, and Miller (2008), intentional restatement refers to restatement arising from irregularities (as opposed to errors that are unintentional).

The proportion of independent directors on the board.

Indicator variable equal to one if there is at least one blockholder 
Duality (1/0)

Dual-class (1/0)

Herfindahl Index

Market share

Cash compensation

CEO delta

CEO vega

Liability expansion event (1/0) owning more than $10 \%$ of the firm's shares and zero otherwise.

Indicator variable equal to one if the positions of chief executive officer (CEO) and board chairman are occupied by the same person and zero otherwise.

Indicator variable equal to one if the company has a dual-class share structure and zero otherwise.

The sum of squared firm market shares for each Fama and French 30 industry in a year using sample and other Canadian firms.

The proportion of a firm's sales relative to the corresponding Fama and French 30 industry in a year using sample and other Canadian firms.

Natural logarithm of (1 plus salary plus bonus plus other annual compensation).

CEO's portfolio sensitivity to a $\$ 1$ increase in the stock price (in thousands).

CEO's portfolio sensitivity to a $1 \%$ change in stock return volatility (in thousands).

Indicator variable equal to one for years after 2005 and zero otherwise. 


\section{Table 2}

\section{Summary statistics.}

Panel A presents summary statistics for the variables used in our directors' and officers' (D\&O) insurance and loan spread analysis. Panel B compares average loan spreads between the group of firms that do not have insurance and the group of firms that have insurance and their insurance coverage ratio is above the median coverage ratio for the sample of firms with insurance. ${ }^{* * *}$ indicates that the statistic is significantly different from zero at the 0.01 level using a two-tailed $t$-test. Variable definitions are in Table 1.

Panel A: Summary statistics for firm and loan characteristics

\begin{tabular}{lcccccc}
\hline & & & \multicolumn{3}{c}{ Percentiles } & \\
\cline { 5 - 6 } Variable & Mean & Standard & $25^{\text {th }}$ & $50^{\text {th }}$ & $75^{\text {th }}$ & $N$ \\
\hline Insurance (1/0) & 0.720 & 0.449 & 0 & 1 & 1 & 615 \\
Coverage amount (US\$m) & 51.288 & 72.145 & 0 & 25 & 75 & 615 \\
Insurance coverage ratio & 0.065 & 0.141 & 0 & 0.020 & 0.056 & 615 \\
Loan spread (basis points) & 181.808 & 125.299 & 75 & 150 & 250 & 615 \\
Loan size (US\$m) & 450.107 & 796.363 & 75 & 200 & 498.750 & 615 \\
Performance pricing (1/0) & 0.239 & 0.427 & 0 & 0 & 0 & 615 \\
Ln(assets) & 7.367 & 1.480 & 6.264 & 7.215 & 8.484 & 609 \\
Market-to-book & 1.532 & 0.683 & 1.109 & 1.365 & 1.732 & 595 \\
Profitability & 0.076 & 0.102 & 0.030 & 0.074 & 0.130 & 604 \\
Leverage & 0.289 & 0.191 & 0.150 & 0.284 & 0.405 & 606 \\
Cash flow volatility & -3.507 & 1.017 & -4.158 & -3.470 & -2.937 & 582 \\
Tangibility & 0.488 & 0.263 & 0.293 & 0.480 & 0.692 & 608 \\
Independent directors & 0.736 & 0.162 & 0.625 & 0.750 & 0.875 & 605 \\
Blockholder (1/0) & 0.555 & 0.497 & 0 & 1 & 1 & 598 \\
Duality (1/0) & 0.886 & 0.318 & 1 & 1 & 1 & 595 \\
Dual-class (1/0) & 0.177 & 0.382 & 0 & 0 & 0 & 605 \\
Herfindahl Index & 0.172 & 0.144 & 0.084 & 0.128 & 0.205 & 610 \\
\hline
\end{tabular}

Panel B: Loan spread comparison by insurance coverage groups

\begin{tabular}{lcccccc}
\hline \multirow{2}{*}{ Variable } & \multicolumn{2}{c}{$\begin{array}{c}\text { Firms in the no- } \\
\text { coverage group (L) }\end{array}$} & \multicolumn{2}{c}{ Firms in the high } & \multirow{2}{c}{$\begin{array}{c}\text { Difference } \\
\text { coverage group (H) }\end{array}$} & \multirow{2}{*}{ (L-H) } \\
\cline { 2 - 5 } & Mean & $N$ & Mean & $N$ & \\
\hline Insurance coverage ratio & 0 & 172 & 0.164 & 220 & - \\
Loan spread (basis points) & 151.538 & 172 & 240.000 & 220 & \multirow{2}{*}{$-88.461^{* * *}$} \\
\hline
\end{tabular}




\section{Table 3}

Directors' and officers' insurance coverage groups and loan spreads.

This table shows the results from ordinary least squares regressions of loan spreads on indicator variables for D\&O insurance coverage. Loan spreads are measured in percentage points. The coefficients on the constant, year and industry fixed effects, and credit rating, loan type, and loan purpose indicators are omitted for brevity. Standard errors (clustered at the firm level) that are robust to both cross-sectional heteroskedasticity and within-firm serial correlation are used in computing t-statistics (in square brackets). ${ }^{*},{ }^{* *}$, or ${ }^{* * *}$ indicates that the coefficient is statistically significantly different from zero at the $0.10,0.05$, or 0.01 level using a two-tailed $t$-test, respectively. Variable definitions are in Table 1.

\begin{tabular}{|c|c|c|c|c|}
\hline Independent variable & $(1)$ & $(2)$ & $(3)$ & $(4)$ \\
\hline Moderate coverage indicator & $\begin{array}{c}0.189 \\
{[1.092]}\end{array}$ & $\begin{array}{c}0.191 \\
{[1.104]}\end{array}$ & $\begin{array}{c}0.125 \\
{[0.770]}\end{array}$ & $\begin{array}{c}0.163 \\
{[0.925]}\end{array}$ \\
\hline High coverage indicator & $\begin{array}{l}0.439^{* * *} \\
{[2.642]}\end{array}$ & $\begin{array}{l}0.424^{* *} \\
{[2.574]}\end{array}$ & $\begin{array}{c}0.284^{*} \\
{[1.899]}\end{array}$ & $\begin{array}{l}0.373^{* *} \\
{[2.258]}\end{array}$ \\
\hline Ln(assets) & $\begin{array}{c}-0.395^{* * *} \\
{[-8.594]}\end{array}$ & $\begin{array}{c}-0.300^{* * *} \\
{[-5.096]}\end{array}$ & $\begin{array}{c}-0.248^{* * *} \\
{[-4.628]}\end{array}$ & $\begin{array}{c}-0.219^{* * *} \\
{[-3.515]}\end{array}$ \\
\hline Market-to-book & $\begin{array}{c}-0.153 \\
{[-1.581]}\end{array}$ & $\begin{array}{c}-0.114 \\
{[-1.163]}\end{array}$ & $\begin{array}{c}-0.104 \\
{[-1.041]}\end{array}$ & $\begin{array}{c}-0.087 \\
{[-0.867]}\end{array}$ \\
\hline Profitability & $\begin{array}{l}-1.380^{* *} \\
{[-2.195]}\end{array}$ & $\begin{array}{l}-1.181^{*} \\
{[-1.864]}\end{array}$ & $\begin{array}{l}-1.258^{*} \\
{[-1.851]}\end{array}$ & $\begin{array}{c}-2.181^{* * *} \\
{[-3.179]}\end{array}$ \\
\hline Leverage & $\begin{array}{c}0.848^{*} \\
{[1.692]}\end{array}$ & $\begin{array}{c}0.869^{*} \\
{[1.741]}\end{array}$ & $\begin{array}{l}1.024^{* *} \\
{[2.012]}\end{array}$ & $\begin{array}{c}0.797 \\
{[1.565]}\end{array}$ \\
\hline Cash flow volatility & $\begin{array}{l}0.126^{* *} \\
{[2.092]}\end{array}$ & $\begin{array}{l}0.131^{* *} \\
{[2.243]}\end{array}$ & $\begin{array}{l}0.132^{* *} \\
{[2.282]}\end{array}$ & $\begin{array}{l}0.156^{* * *} \\
{[2.638]}\end{array}$ \\
\hline Tangibility & $\begin{array}{c}-0.461 \\
{[-1.219]}\end{array}$ & $\begin{array}{c}-0.580 \\
{[-1.536]}\end{array}$ & $\begin{array}{c}-0.371 \\
{[-0.992]}\end{array}$ & $\begin{array}{c}-0.196 \\
{[-0.539]}\end{array}$ \\
\hline Ln(loan size) & & $\begin{array}{l}-0.133^{* *} \\
{[-2.463]}\end{array}$ & $\begin{array}{l}-0.153^{* * *} \\
{[-3.070]}\end{array}$ & $\begin{array}{c}-0.170^{* * *} \\
{[-2.991]}\end{array}$ \\
\hline Performance pricing (1/0) & & $\begin{array}{c}-0.171 \\
{[-1.632]}\end{array}$ & $\begin{array}{c}-0.147 \\
{[-1.268]}\end{array}$ & $\begin{array}{c}-0.028 \\
{[-0.248]}\end{array}$ \\
\hline Independent directors & & & & $\begin{array}{c}-0.564 \\
{[-1.223]}\end{array}$ \\
\hline Blockholder (1/0) & & & & $\begin{array}{c}-0.101 \\
{[-0.802]}\end{array}$ \\
\hline Duality (1/0) & & & & $\begin{array}{c}-0.091 \\
{[-0.433]}\end{array}$ \\
\hline Dual-class (1/0) & & & & $\begin{array}{c}0.266 \\
{[1.265]}\end{array}$ \\
\hline Herfindahl Index & & & & $\begin{array}{c}-0.041 \\
{[-0.071]}\end{array}$ \\
\hline Credit rating indicators & Yes & Yes & Yes & Yes \\
\hline Loan type indicators & No & No & Yes & Yes \\
\hline Loan purpose indicators & No & No & Yes & Yes \\
\hline Industry effects & Yes & Yes & Yes & Yes \\
\hline Year effects & No & No & No & Yes \\
\hline $\begin{array}{l}\text { Adjusted } R^{2} \\
N\end{array}$ & $\begin{array}{c}0.413 \\
570\end{array}$ & $\begin{array}{c}0.424 \\
570\end{array}$ & $\begin{array}{c}0.482 \\
570\end{array}$ & $\begin{array}{c}0.517 \\
546\end{array}$ \\
\hline
\end{tabular}




\section{Table 4}

Directors’ and officers’ insurance coverage and loan spreads.

This table shows the results from ordinary least squares regressions of loan spreads on the D\&O insurance coverage ratio. Loan spreads are measured in percentage points. The coefficients on the constant, year and industry fixed effects, and credit rating, loan type, and loan purpose indicators are omitted for brevity. Standard errors (clustered at the firm level) that are robust to both cross-sectional heteroskedasticity and within-firm serial correlation are used in computing t-statistics (in square brackets). ${ }^{*},{ }^{* *}$, or ${ }^{* * *}$ indicates that the coefficient is statistically significantly different from zero at the $0.10,0.05$, or 0.01 level using a two-tailed $t$-test, respectively. Variable definitions are in Table 1.

\begin{tabular}{|c|c|c|c|c|}
\hline Independent variable & $(1)$ & $(2)$ & $(3)$ & $(4)$ \\
\hline \multirow[t]{2}{*}{ Insurance coverage ratio } & $1.383^{* *}$ & $1.327^{* *}$ & $1.213^{* *}$ & $1.347^{* * *}$ \\
\hline & {$[2.341]$} & {$[2.246]$} & [2.059] & [2.891] \\
\hline \multirow[t]{2}{*}{ Ln(assets) } & $-0.382^{* * *}$ & $-0.289^{* * *}$ & $-0.232^{* * *}$ & $-0.197^{* * *}$ \\
\hline & {$[-9.510]$} & {$[-5.200]$} & {$[-4.768]$} & [-3.623] \\
\hline \multirow[t]{2}{*}{ Market-to-book } & -0.139 & -0.100 & -0.082 & -0.072 \\
\hline & {$[-1.563]$} & {$[-1.115]$} & {$[-0.890]$} & {$[-0.756]$} \\
\hline \multirow[t]{2}{*}{ Profitability } & $-1.301^{* *}$ & $-1.105^{*}$ & $-1.192^{*}$ & $-2.093^{* * *}$ \\
\hline & {$[-2.180]$} & {$[-1.828]$} & {$[-1.855]$} & [-3.196] \\
\hline \multirow[t]{2}{*}{ Leverage } & $0.837^{*}$ & $0.859^{*}$ & $1.021^{* *}$ & $0.862^{* *}$ \\
\hline & [1.855] & [1.904] & {$[2.262]$} & [2.044] \\
\hline \multirow[t]{2}{*}{ Cash flow volatility } & $0.123^{*}$ & $0.130^{* *}$ & $0.131^{* *}$ & $0.158^{* *}$ \\
\hline & [1.952] & [2.110] & [2.174] & [2.597] \\
\hline \multirow[t]{2}{*}{ Tangibility } & -0.563 & $-0.678^{*}$ & -0.449 & -0.296 \\
\hline & {$[-1.481]$} & {$[-1.787]$} & {$[-1.203]$} & [-0.809] \\
\hline \multirow[t]{2}{*}{ Ln(loan size $)$} & & $-0.126^{* *}$ & $-0.151^{* * *}$ & $-0.176^{* * *}$ \\
\hline & & {$[-2.309]$} & {$[-3.005]$} & [-3.075] \\
\hline \multirow[t]{2}{*}{ Performance pricing (1/0) } & & $-0.189^{*}$ & -0.152 & -0.037 \\
\hline & & {$[-1.786]$} & {$[-1.295]$} & {$[-0.336]$} \\
\hline \multirow[t]{2}{*}{ Independent directors } & & & & -0.588 \\
\hline & & & & [-1.356] \\
\hline \multirow[t]{2}{*}{ Blockholder (1/0) } & & & & -0.156 \\
\hline & & & & [-1.245] \\
\hline \multirow[t]{2}{*}{ Duality (1/0) } & & & & -0.089 \\
\hline & & & & [-0.415] \\
\hline \multirow[t]{2}{*}{ Dual-class (1/0) } & & & & 0.232 \\
\hline & & & & [1.173] \\
\hline \multirow[t]{2}{*}{ Herfindahl Index } & & & & -0.019 \\
\hline & & & & [-0.034] \\
\hline Credit rating indicators & Yes & Yes & Yes & Yes \\
\hline Loan type indicators & No & No & Yes & Yes \\
\hline Loan purpose indicators & No & No & Yes & Yes \\
\hline Industry effects & Yes & Yes & Yes & Yes \\
\hline Year effects & No & No & No & Yes \\
\hline Adjusted $R^{2}$ & 0.416 & 0.427 & 0.489 & 0.523 \\
\hline$N$ & 570 & 570 & 570 & 546 \\
\hline
\end{tabular}




\section{Table 5}

Loan spread split-sample analyses.

This table shows the results from ordinary least squares regressions of loan spreads on the D\&O insurance coverage ratio and other control variables, based on two subsamples split by loan characteristics and proxies for monitoring. Loan spreads are measured in percentage points. All models control for firm characteristics (i.e., firm size, market-to-book, profitability, leverage, cash flow volatility, tangibility, and credit ratings), governance variables (i.e., independent directors, blockholder, chief executive officer-chair duality, and dual-class indicators, and Herfindahl Index), and loan characteristics (i.e., loan size, performance pricing, loan type, and loan purpose indicators), as well as industry and year indicators. Standard errors (clustered at the firm level) that are robust to both cross-sectional heteroskedasticity and within-firm serial correlation are used in computing t-statistics (in square brackets). ${ }^{*},{ }^{* *}$, or ${ }^{* * *}$ indicates that the coefficient is statistically significantly different from zero at the $0.10,0.05$, or 0.01 level using a two-tailed $t$-test, respectively. Variable definitions are in Table 1.

Panel A: Split by loan maturity

\begin{tabular}{lcc}
\hline & Maturity $\geq 5$ years & Maturity $<5$ years \\
\hline Insurance coverage ratio & $2.006^{* * * *}$ & 0.600 \\
& {$[2.669]$} & {$[1.052]$} \\
& & \\
Adjusted $R^{2}$ & 0.700 & 0.506 \\
$N$ & 252 & 269 \\
\hline
\end{tabular}

Panel B: Split by loan type

\begin{tabular}{lcc}
\hline & Term loan & Non-term loan \\
\hline Insurance coverage ratio & $2.894^{* *}$ & $0.879^{* *}$ \\
& {$[2.556]$} & {$[2.442]$} \\
& & \\
Adjusted $R^{2}$ & 0.539 & 0.487 \\
$N$ & 153 & 393 \\
\hline
\end{tabular}

Panel C: Split by whether the loan is for acquisition purposes

\begin{tabular}{lcc}
\hline & Yes & No \\
\hline Insurance coverage ratio & $7.930^{* * *}$ & $1.447^{* *}$ \\
& {$[2.866]$} & {$[2.594]$} \\
& & \\
Adjusted $R^{2}$ & 0.631 & 0.536 \\
$N$ & 138 & 408 \\
\hline
\end{tabular}

Panel D: Split by analyst following

\begin{tabular}{lcc}
\hline & $\begin{array}{c}\text { Number of analysts } \\
\geq \text { median }\end{array}$ & $\begin{array}{c}\text { Number of analysts } \\
<\text { median }\end{array}$ \\
\hline Insurance coverage ratio & 0.047 & $2.044^{* * *}$ \\
& {$[0.116]$} & {$[3.645]$} \\
Adjusted $R^{2}$ & & \\
$N$ & 0.566 & 0.522 \\
\hline
\end{tabular}


Panel E: Split by the existence of a blockholder

\begin{tabular}{lcc}
\hline & Yes & No \\
\hline Insurance coverage ratio & $0.759^{* *}$ & $3.746^{* *}$ \\
& {$[1.990]$} & {$[2.512]$} \\
& & \\
Adjusted $R^{2}$ & 0.610 & 0.584 \\
$N$ & 308 & 238 \\
\hline
\end{tabular}

Panel F: Split by prior lending relations

\begin{tabular}{lcc}
\hline & Yes & No \\
\hline Insurance coverage ratio & -0.038 & $2.597^{* * *}$ \\
& {$[-0.074]$} & {$[4.430]$} \\
Adjusted $R^{2}$ & & \\
$N$ & 0.659 & 0.530 \\
\hline
\end{tabular}




\section{Table 6}

Directors’ and officers’ insurance coverage and loan spreads_-Ontario Bill 198 and change regression.

Panel A shows the results from an ordinary least squares regression of loan spreads on the D\&O insurance coverage ratio, an indicator variable for expanded liability from 2006 onward (as a result of an exogenous regulatory change, Ontario Bill 198 [Liability expansion event (1/0) equals one for observations from 2006 onwards and zero otherwise]), and the interaction term between insurance coverage and the regulatory change indicator variable. Loan spreads are measured in percentage points. The coefficients on the constant, year and industry fixed effects, and credit rating, loan type, and loan purpose indicators are omitted for brevity. Standard errors (clustered at the firm level) that are robust to both cross-sectional heteroskedasticity and within-firm serial correlation are used in computing $t$-statistics (in square brackets). Panel B presents results from a median regression of changes in loan spread on changes in insurance coverage. To compute $\Delta$ Loan spread, we use only the largest loan facility (by dollar amount) per firm per year and compute differences in spreads between consecutive loans (which in rare instances are multiple years apart). All difference variables in Panel B are calculated using the same differencing period as for the loan spread (typically one-year changes). $\Delta$ Credit rating is the change in an ordinal rating coded from the Standard \& Poor's credit rating in the following way: $1=\mathrm{AAA}, 2=\mathrm{AA}, 3=\mathrm{A}, 4=$ BBB, $5=\mathrm{BB}, 6=\mathrm{B}$ or worse, and $7=$ no rating. In both panels ${ }^{*},{ }^{* *}$, or ${ }^{* * *}$ indicates that the coefficient is statistically significantly different from zero at the $0.10,0.05$, or 0.01 level using a two-tailed $t$-test, respectively. Variable definitions are in Table 1.

Panel A: Loan spread regressions - Ontario Bill 198

\begin{tabular}{|c|c|}
\hline Independent variable & \\
\hline \multirow[t]{2}{*}{ Insurance coverage ratio } & $1.282^{* * *}$ \\
\hline & {$[2.724]$} \\
\hline \multirow[t]{2}{*}{ Insurance coverage ratio*Liability expansion event (1/0) } & $4.735^{* *}$ \\
\hline & [1.966] \\
\hline \multirow[t]{2}{*}{ Liability expansion event (1/0) } & 0.254 \\
\hline & {$[1.353]$} \\
\hline \multirow[t]{2}{*}{ Ln(assets) } & $-0.184^{* * *}$ \\
\hline & {$[-3.343]$} \\
\hline \multirow[t]{2}{*}{ Market-to-book } & -0.060 \\
\hline & {$[-0.622]$} \\
\hline \multirow[t]{2}{*}{ Profitability } & $-2.070^{* * *}$ \\
\hline & {$[-3.110]$} \\
\hline \multirow[t]{2}{*}{ Leverage } & $0.900^{* *}$ \\
\hline & {$[2.230]$} \\
\hline \multirow[t]{2}{*}{ Cash flow volatility } & $0.158^{* * *}$ \\
\hline & {$[2.694]$} \\
\hline \multirow[t]{2}{*}{ Tangibility } & -0.320 \\
\hline & {$[-0.881]$} \\
\hline \multirow[t]{2}{*}{ Ln(loan size) } & $-0.180^{* * *}$ \\
\hline & {$[-3.146]$} \\
\hline \multirow[t]{2}{*}{ Performance pricing $(1 / 0)$} & -0.052 \\
\hline & {$[-0.451]$} \\
\hline \multirow[t]{2}{*}{ Independent directors } & -0.519 \\
\hline & {$[-1.179]$} \\
\hline \multirow[t]{2}{*}{ Blockholder (1/0) } & -0.166 \\
\hline & {$[-1.295]$} \\
\hline \multirow[t]{2}{*}{ Duality (1/0) } & -0.065 \\
\hline & {$[-0.282]$} \\
\hline Dual-class (1/0) & 0.291 \\
\hline
\end{tabular}


Herfindahl Index

[1.466]

$-0.044$

[-0.080]

Credit rating indicators

Yes

Loan type indicators

Yes

Loan purpose indicators

Yes

Industry and year effects

Yes

Adjusted $R^{2}$

0.524

$N$

546

Panel B: Change regression

\begin{tabular}{lc}
\hline Independent variable & \\
\hline$\Delta$ Insurance coverage ratio & $1.218^{* * *}$ \\
$\Delta$ Ln(assets) & {$[4.240]$} \\
$\Delta$ Market-to-book & $-0.181^{* *}$ \\
& {$[-2.272]$} \\
$\Delta$ Profitability & -0.093 \\
& {$[-1.516]$} \\
$\Delta$ Leverage & $-2.130^{* * *}$ \\
& {$[-4.344]$} \\
$\Delta$ Cash flow volatility & -0.172 \\
& {$[-0.643]$} \\
$\Delta$ Tangibility & $0.107^{* *}$ \\
& {$[2.362]$} \\
$\Delta$ Ln(loan size) & 0.422 \\
$\Delta$ Credit rating & {$[1.002]$} \\
$\Delta$ Independent directors & $-0.106^{* *}$ \\
$\Delta$ Herfindahl Index & {$[-2.569]$} \\
& -0.031 \\
Adjusted $R^{2}$ & {$[-0.575]$} \\
& -0.409 \\
& {$[-0.969]$} \\
& -0.502 \\
& {$[-0.876]$}
\end{tabular}




\section{Table 7}

\section{Directors’ and officers’ insurance coverage and firm risk taking.}

Panel A presents the summary statistics for firm risk measures and $t$-tests for differences in means for low and high D\&O insurance coverage groups. The low (high) coverage group is defined as having insurance coverage ratio below (above) the median of the insurance coverage ratio distribution in the sample with insurance coverage and risk data. Total risk is the natural logarithm of the annualized variance of daily percentage returns over the fiscal year. Idiosyncratic risk is the natural logarithm of the annualized variance of the residuals from the market model. All other variables are defined in Table 1. Panel B shows the results from regressing firm risk on the D\&O insurance coverage ratio. The sample used in the analysis is the intersection of the D\&O insurance sample, Compustat, Datastream share prices, and corporate governance variables. Coverage and all control variables are lagged by one year relative to risk measures. OLS indicates ordinary least squares regressions while FE indicates regressions with firm fixed effects. IV indicates instrumental variables regressions in which the $\mathrm{D} \& \mathrm{O}$ insurance coverage ratio is instrumented with fitted values from a first-stage regression on the industry/year median insurance coverage ratio (based on Fama and French 30 industry classifications) and the control variables. Shea's (1997) partial $R^{2}$ is a measure of instrumental variable (IV) relevance. The first-stage $F$-test is the test of excluded IV in the first-stage regression. Standard errors (clustered at the firm level) that are robust to both cross-sectional heteroskedasticity and within-firm serial correlation are used in computing $t$-statistics (in square brackets). The coefficients on the constant, and year, industry, and firm fixed effects are omitted for brevity. Panel C presents the results from median regression of changes in risk measures on changes in insurance coverage and changes in other firm-level characteristics. In all panels ${ }^{*},{ }^{* *}$, or ${ }^{* * *}$ indicates that the coefficient (or statistic) is statistically significantly different from zero at the $0.10,0.05$, or 0.01 level using a two-tailed $t$-test, respectively.

Panel A: Risk proxies by coverage groups

\begin{tabular}{|c|c|c|c|c|c|c|c|c|}
\hline \multirow[b]{2}{*}{ Variable } & \multicolumn{3}{|c|}{ All } & \multicolumn{2}{|c|}{$\begin{array}{l}\text { Firms in the low } \\
\text { coverage group (L) }\end{array}$} & \multicolumn{2}{|c|}{$\begin{array}{l}\text { Firms in the high } \\
\text { coverage group }(\mathrm{H})\end{array}$} & \multirow[b]{2}{*}{$\begin{array}{l}\text { Difference } \\
\quad(\mathrm{L}-\mathrm{H})\end{array}$} \\
\hline & Mean & $\begin{array}{l}\text { Standard } \\
\text { deviation }\end{array}$ & $N$ & Mean & $N$ & Mean & $N$ & \\
\hline Insurance coverage ratio & 0.076 & 0.168 & 2,891 & 0.005 & 1,445 & 0.148 & 1,446 & - \\
\hline Total risk (log) & 7.667 & 1.110 & 2,891 & 7.590 & 1,445 & 7.743 & 1,446 & $-0.152^{* * *}$ \\
\hline Idiosyncratic risk (log) & 7.562 & 1.131 & 2,891 & 7.449 & 1,445 & 7.676 & 1,446 & $-0.227^{* * *}$ \\
\hline
\end{tabular}


Panel B: Regression results

\begin{tabular}{|c|c|c|c|c|c|c|}
\hline \multirow[b]{2}{*}{ Independent variable } & \multicolumn{3}{|c|}{ Total risk } & \multicolumn{3}{|c|}{ Idiosyncratic risk } \\
\hline & $\begin{array}{c}\text { OLS } \\
(1)\end{array}$ & $\begin{array}{l}\mathrm{FE} \\
(2)\end{array}$ & $\begin{array}{l}\text { IV } \\
\text { (3) }\end{array}$ & $\begin{array}{l}\text { OLS } \\
(4)\end{array}$ & $\begin{array}{l}\mathrm{FE} \\
(5) \\
\end{array}$ & $\begin{array}{l}\text { IV } \\
(6)\end{array}$ \\
\hline \multirow[t]{2}{*}{ Insurance coverage ratio } & $1.116^{* * *}$ & $0.681^{* * *}$ & $0.686^{* *}$ & $1.134^{* * *}$ & $0.708^{* * *}$ & $0.734^{* *}$ \\
\hline & {$[7.040]$} & [4.140] & {$[2.044]$} & [7.083] & [4.219] & [2.102] \\
\hline \multirow[t]{2}{*}{ Ln(assets) } & $-0.283^{* * *}$ & $-0.111^{* * *}$ & $-0.121^{* * *}$ & $-0.326^{* * *}$ & $-0.156^{* * *}$ & $-0.166^{* *}$ \\
\hline & {$[-13.414]$} & {$[-3.246]$} & {$[-3.695]$} & {$[-15.851]$} & {$[-4.686]$} & {$[-5.174]$} \\
\hline \multirow[t]{2}{*}{ Market-to-book } & $-0.043^{* *}$ & $-0.057^{* * *}$ & $-0.063^{* * *}$ & $-0.059^{* * *}$ & $-0.075^{* * *}$ & $-0.081^{* *}$ \\
\hline & {$[-2.506]$} & {$[-3.691]$} & {$[-3.884]$} & {$[-3.439]$} & {$[-5.005]$} & {$[-5.046]$} \\
\hline \multirow[t]{2}{*}{ Leverage } & $0.291^{* *}$ & 0.345 & 0.341 & $0.324^{* *}$ & 0.370 & 0.364 \\
\hline & [2.396] & [1.630] & [1.379] & [2.496] & [1.608] & [1.364] \\
\hline \multirow[t]{2}{*}{$\mathrm{R} \& \mathrm{D}$} & $1.537^{* * *}$ & $0.776^{* *}$ & $0.831^{* *}$ & $1.467^{* * *}$ & $0.733^{* *}$ & $0.789^{* *}$ \\
\hline & [3.959] & [2.082] & {$[2.292]$} & [3.851] & [2.003] & [2.214] \\
\hline \multirow[t]{2}{*}{ Capex } & 0.292 & 0.118 & 0.180 & 0.210 & 0.078 & 0.147 \\
\hline & [1.075] & [0.459] & [0.691] & [0.773] & [0.306] & [0.564] \\
\hline \multirow[t]{2}{*}{ Cash compensation } & -0.013 & -0.008 & -0.010 & -0.012 & -0.009 & -0.011 \\
\hline & {$[-1.083]$} & {$[-0.626]$} & {$[-0.799]$} & {$[-1.042]$} & {$[-0.734]$} & {$[-0.913]$} \\
\hline \multirow[t]{2}{*}{ CEO delta } & $0.001^{* *}$ & 0.001 & 0.001 & 0.001 & 0.001 & 0.001 \\
\hline & {$[2.498]$} & [1.512] & [1.489] & [1.437] & [0.088] & [0.052] \\
\hline \multirow[t]{2}{*}{ CEO vega } & $0.003^{* * *}$ & 0.001 & 0.001 & $0.003^{* * *}$ & 0.001 & 0.001 \\
\hline & [3.677] & {$[0.441]$} & [0.387] & [4.084] & {$[0.585]$} & [0.523] \\
\hline Firm effects & No & Yes & Yes & No & Yes & Yes \\
\hline Industry effects & Yes & Yes & Yes & Yes & Yes & Yes \\
\hline Year effects & Yes & Yes & Yes & Yes & Yes & Yes \\
\hline First-stage Shea's partial $R^{2}$ & & & 0.154 & & & 0.154 \\
\hline First-stage $F$-test ( $p$-value) & & & 0.000 & & & 0.000 \\
\hline Adjusted $R^{2}$ & 0.583 & 0.330 & 0.323 & 0.602 & 0.407 & 0.399 \\
\hline$N$ & 2,891 & 2,891 & 2,891 & 2,891 & 2,891 & 2,891 \\
\hline
\end{tabular}


Panel C: Change regressions

\begin{tabular}{lcc}
\hline Independent variable & $\Delta$ Total risk & $\Delta$ Idiosyncratic risk \\
\hline$\Delta$ Insurance coverage ratio & $0.374^{* *}$ & $0.376^{* *}$ \\
& {$[2.444]$} & {$[2.108]$} \\
$\Delta$ Ln(assets) & -0.057 & $-0.088^{* *}$ \\
& {$[-1.528]$} & {$[-2.013]$} \\
$\Delta$ Market-to-book & $-0.013^{*}$ & $-0.017^{* *}$ \\
$\Delta$ Leverage & {$[-1.769]$} & {$[-2.049]$} \\
& -0.008 & -0.006 \\
$\Delta$ R\&D & {$[-0.103]$} & {$[-0.064]$} \\
& 0.315 & 0.285 \\
$\Delta$ Capex & {$[1.366]$} & {$[1.059]$} \\
& 0.010 & 0.017 \\
$\Delta$ Cash compensation & {$[0.062]$} & {$[0.089]$} \\
& -0.008 & -0.008 \\
$\Delta$ CEO delta & {$[-0.785]$} & {$[-0.700]$} \\
$\Delta$ CEO vega & 0.001 & 0.001 \\
& {$[1.005]$} & {$[0.175]$} \\
Adjusted $R^{2}$ & -0.001 & 0.001 \\
$N$ & {$[-0.006]$} & {$[0.065]$} \\
\end{tabular}




\section{Table 8}

Directors' and officers' insurance coverage and earnings restatements.

Panel A presents the summary statistics for the incidence of earnings restatements and $t$-tests for differences in means for low and high insurance coverage groups. The low (high) coverage group is defined as having insurance coverage ratio below (above) the median of the insurance coverage ratio distribution in the sample with insurance coverage and restatement data. Panel B shows the results from regressing the incidence of earnings restatement on the $\mathrm{D} \& \mathrm{O}$ insurance coverage ratio. The sample used in the analysis is the intersection of the D\&O insurance sample, Compustat, and hand-collected restatement information. Coverage and all control variables are lagged by one year relative to the restatement variables. Columns 1 and 4 contain linear probability model with firm fixed effects (FE). Columns 2 and 5 contain probit models. Columns 3 and 6 report probit models based on an instrumental variables (IV) approach, in which the D\&O insurance coverage is instrumented with fitted values from a first-stage regression on the industry/year median insurance coverage ratio (based on Fama and French 30 industry classifications) and the control variables. In Columns 2, 3, 5, and 6 marginal effects from the underlying probit coefficients are reported. The marginal effect of an indicator variable is calculated as the discrete change in the expected value of the dependent variable as the indicator variable changes from zero to one. Shea's (1997) partial $R^{2}$ is a measure of IV relevance. The first-stage F-test is the test of excluded IV in the first-stage regression. Standard errors (clustered at the firm level) that are robust to both cross-sectional heteroskedasticity and within-firm serial correlation are used in computing $t$-statistics (in square brackets). The coefficients on the constant, and year, industry, and firm fixed effects are omitted for brevity. Panel C presents the results from probit regression of the incidence of earnings restatement on changes in insurance coverage and changes in other firm-level characteristics. In both columns marginal effects from the underlying probit coefficients are reported. In all panels ${ }^{*},{ }^{* *},{ }^{* * *}$ indicates that the coefficient (or statistic) is statistically significantly different from zero at the $0.10,0.05$, or 0.01 level using a two-tailed $t$-test, respectively. Variable definitions are in Table 1.

Panel A: Earnings restatements by coverage groups

\begin{tabular}{|c|c|c|c|c|c|c|c|c|}
\hline \multirow[b]{2}{*}{ Variable } & \multicolumn{3}{|c|}{ All } & \multicolumn{2}{|c|}{$\begin{array}{l}\text { Firms in the low } \\
\text { coverage group (L) }\end{array}$} & \multicolumn{2}{|c|}{$\begin{array}{l}\text { Firms in the high } \\
\text { coverage group }(\mathrm{H})\end{array}$} & \multirow[b]{2}{*}{$\begin{array}{l}\text { Difference } \\
(\mathrm{L}-\mathrm{H})\end{array}$} \\
\hline & Mean & $\begin{array}{l}\text { Standard } \\
\text { deviation }\end{array}$ & $N$ & Mean & $N$ & Mean & $N$ & \\
\hline Insurance coverage ratio & 0.063 & 0.125 & 3,208 & 0.004 & 1,604 & 0.122 & 1,604 & - \\
\hline Restatement indicator & 0.055 & 0.228 & 3,208 & 0.022 & 1,604 & 0.088 & 1,604 & $-0.066^{* * *}$ \\
\hline Intentional restatement indicator & 0.049 & 0.215 & 3,208 & 0.014 & 1,604 & 0.083 & 1,604 & $-0.069^{* * *}$ \\
\hline
\end{tabular}


Panel B: Regression results

\begin{tabular}{|c|c|c|c|c|c|c|}
\hline \multirow[b]{2}{*}{ Independent variable } & \multicolumn{3}{|c|}{ Restatement indicator } & \multicolumn{3}{|c|}{ Intentional restatement indicator } \\
\hline & $\begin{array}{l}\text { FE } \\
(1)\end{array}$ & $\begin{array}{l}\text { Probit } \\
\text { (2) }\end{array}$ & $\begin{array}{l}\text { IV-probit } \\
\text { (3) }\end{array}$ & $\begin{array}{l}\mathrm{FE} \\
(4)\end{array}$ & $\begin{array}{l}\text { Probit } \\
\text { (5) }\end{array}$ & $\begin{array}{c}\text { IV-probit } \\
(6)\end{array}$ \\
\hline Insurance coverage ratio & $\begin{array}{l}0.173^{* *} \\
{[2.455]}\end{array}$ & $\begin{array}{l}0.120^{* * *} \\
{[5.303]}\end{array}$ & $\begin{array}{c}0.135^{*} \\
{[1.738]}\end{array}$ & $\begin{array}{l}0.172^{* *} \\
{[2.524]}\end{array}$ & $\begin{array}{l}0.108^{* * *} \\
{[5.264]}\end{array}$ & $\begin{array}{c}0.140^{*} \\
{[1.949]}\end{array}$ \\
\hline Ln(assets) & $\begin{array}{c}0.001 \\
{[0.097]}\end{array}$ & $\begin{array}{l}0.009^{* * *} \\
{[2.598]}\end{array}$ & $\begin{array}{c}0.007^{*} \\
{[1.958]}\end{array}$ & $\begin{array}{c}-0.007 \\
{[-0.732]}\end{array}$ & $\begin{array}{c}0.005^{*} \\
{[1.664]}\end{array}$ & $\begin{array}{c}0.003 \\
{[1.079]}\end{array}$ \\
\hline Market-to-book & $\begin{array}{c}-0.001 \\
{[-0.253]}\end{array}$ & $\begin{array}{c}-0.004 \\
{[-1.077]}\end{array}$ & $\begin{array}{c}-0.006 \\
{[-1.301]}\end{array}$ & $\begin{array}{c}-0.001 \\
{[-0.229]}\end{array}$ & $\begin{array}{c}-0.005 \\
{[-1.432]}\end{array}$ & $\begin{array}{c}-0.006 \\
{[-1.550]}\end{array}$ \\
\hline Leverage & $\begin{array}{c}0.057 \\
{[1.000]}\end{array}$ & $\begin{array}{c}0.049^{*} \\
{[1.740]}\end{array}$ & $\begin{array}{c}0.054^{*} \\
{[1.857]}\end{array}$ & $\begin{array}{c}0.051 \\
{[0.910]}\end{array}$ & $\begin{array}{c}0.035 \\
{[1.362]}\end{array}$ & $\begin{array}{c}0.039 \\
{[1.461]}\end{array}$ \\
\hline Profitability & $\begin{array}{c}0.005 \\
{[0.106]}\end{array}$ & $\begin{array}{c}-0.036 \\
{[-1.367]}\end{array}$ & $\begin{array}{c}-0.043 \\
{[-1.573]}\end{array}$ & $\begin{array}{c}-0.018 \\
{[-0.415]}\end{array}$ & $\begin{array}{c}-0.046^{*} \\
{[-1.951]}\end{array}$ & $\begin{array}{l}-0.052^{* *} \\
{[-2.106]}\end{array}$ \\
\hline Sales growth & $\begin{array}{c}-0.012 \\
{[-1.083]}\end{array}$ & $\begin{array}{c}-0.007 \\
{[-0.738]}\end{array}$ & $\begin{array}{c}-0.008 \\
{[-0.827]}\end{array}$ & $\begin{array}{c}-0.015 \\
{[-1.416]}\end{array}$ & $\begin{array}{c}-0.010 \\
{[-1.236]}\end{array}$ & $\begin{array}{c}-0.011 \\
{[-1.262]}\end{array}$ \\
\hline Stock return in prior year & $\begin{array}{c}-0.001^{*} \\
{[-1.886]}\end{array}$ & $\begin{array}{c}-0.001^{*} \\
{[-1.686]}\end{array}$ & $\begin{array}{l}-0.001^{*} \\
{[-1.889]}\end{array}$ & $\begin{array}{c}-0.001 \\
{[-1.256]}\end{array}$ & $\begin{array}{c}-0.001 \\
{[-0.982]}\end{array}$ & $\begin{array}{c}-0.001 \\
{[-1.138]}\end{array}$ \\
\hline Big-five auditor & $\begin{array}{l}-0.072^{* * *} \\
{[-2.666]}\end{array}$ & $\begin{array}{c}0.011 \\
{[0.748]}\end{array}$ & $\begin{array}{c}0.013 \\
{[0.861]}\end{array}$ & $\begin{array}{l}-0.054^{* *} \\
{[-2.313]}\end{array}$ & $\begin{array}{c}0.010 \\
{[0.717]}\end{array}$ & $\begin{array}{c}0.011 \\
{[0.839]}\end{array}$ \\
\hline Independent directors & $\begin{array}{c}-0.098 \\
{[-1.643]}\end{array}$ & $\begin{array}{c}-0.027 \\
{[-0.912]}\end{array}$ & $\begin{array}{c}-0.028 \\
{[-0.928]}\end{array}$ & $\begin{array}{c}-0.053 \\
{[-0.974]}\end{array}$ & $\begin{array}{c}0.001 \\
{[0.023]}\end{array}$ & $\begin{array}{c}-0.001 \\
{[-0.019]}\end{array}$ \\
\hline Blockholder (1/0) & & $\begin{array}{c}0.003 \\
{[0.317]}\end{array}$ & $\begin{array}{c}0.004 \\
{[0.406]}\end{array}$ & & $\begin{array}{c}0.006 \\
{[0.772]}\end{array}$ & $\begin{array}{c}0.007 \\
{[0.801]}\end{array}$ \\
\hline Duality (1/0) & & $\begin{array}{c}0.011 \\
{[0.795]}\end{array}$ & $\begin{array}{c}0.009 \\
{[0.638]}\end{array}$ & & $\begin{array}{c}0.014 \\
{[1.109]}\end{array}$ & $\begin{array}{c}0.012 \\
{[0.913]}\end{array}$ \\
\hline Dual-class $(1 / 0)$ & & $\begin{array}{c}-0.016 \\
{[-1.304]}\end{array}$ & $\begin{array}{c}-0.016 \\
{[-1.266]}\end{array}$ & & $\begin{array}{c}-0.009 \\
{[-0.754]}\end{array}$ & $\begin{array}{c}-0.008 \\
{[-0.700]}\end{array}$ \\
\hline Firm effects & Yes & No & No & Yes & No & No \\
\hline Industry effects & Yes & Yes & Yes & Yes & Yes & Yes \\
\hline Year effects & Yes & Yes & Yes & Yes & Yes & Yes \\
\hline $\begin{array}{l}\text { First-stage Shea's partial } R^{2} \\
\text { First-stage } F \text {-test ( } p \text {-value) }\end{array}$ & & & $\begin{array}{l}0.125 \\
0.000\end{array}$ & & & $\begin{array}{l}0.125 \\
0.000\end{array}$ \\
\hline Adjusted $R^{2}$ /Pseudo $R^{2}$ & 0.022 & 0.185 & 0.178 & 0.024 & 0.185 & 0.180 \\
\hline$N$ & 2,558 & 2,483 & 2,483 & 2,558 & 2,483 & 2,483 \\
\hline
\end{tabular}


Panel C: Change regressions

\begin{tabular}{lcc}
\hline Independent variable & Restatement indicator & Intentional restatement indicator \\
\hline$\Delta$ Insurance coverage ratio & $0.184^{*}$ & $0.157^{*}$ \\
$\Delta$ Ln(assets) & {$[1.926]$} & {$[1.811]$} \\
& $-0.028^{*}$ & $-0.040^{* *}$ \\
$\Delta$ Market-to-book & {$[-1.786]$} & {$[-2.575]$} \\
& -0.003 & -0.004 \\
$\Delta$ Leverage & {$[-1.492]$} & {$[-1.531]$} \\
& 0.059 & 0.028 \\
$\Delta$ Profitability & {$[1.133]$} & {$[0.503]$} \\
& -0.003 & -0.024 \\
$\Delta$ Sales growth & {$[-0.131]$} & {$[-0.981]$} \\
& -0.004 & -0.005 \\
$\Delta$ Stock return in prior year & {$[-0.553]$} & {$[-0.884]$} \\
& -0.001 & 0.001 \\
$\Delta$ Big-five auditor & {$[-0.277]$} & {$[0.855]$} \\
$\Delta$ Independent directors & $-0.080^{*}$ & $-0.072^{*}$ \\
& {$[-1.817]$} & {$[-1.734]$} \\
Pseudo $R^{2}$ & -0.052 & -0.016 \\
$N$ & {$[-0.903]$} & {$[-0.302]$} \\
\hline
\end{tabular}




\section{Table 9}

Directors' and officers' insurance coverage, governance, and the marginal value of large capital expenditure increases.

This table reports the results from regressions of fiscal-year industry-adjusted excess returns (over returns to a firm's Fama and French 30 portfolio) on large changes in capital expenditures and the interaction with D\&O insurance coverage. The regressions are split by proxies for internal (board independence) and external governance (product market competition). Following Masulis Wang, and Xie (2009), the sample contains only firm-years in which the firm has at least $5 \%$ growth in capital expenditures (Compustat data item 128). Firm-level characteristics, except for leverage, are scaled by the market value of equity at the beginning of fiscal year. The coefficients on the constant, and year and industry fixed effects are omitted for brevity. Standard errors (clustered at the firm level) that are robust to both cross-sectional heteroskedasticity and within-firm serial correlation are used in computing $t$-statistics (in square brackets). ${ }^{*},{ }^{* *}$, or ${ }^{* * *}$ indicates that the coefficient is statistically significantly different from zero at the $0.10,0.05$, or 0.01 level using a twotailed $t$-test, respectively. Variable definitions are in Table 1.

\begin{tabular}{|c|c|c|c|c|c|c|}
\hline \multirow[b]{2}{*}{ Independent variable } & \multicolumn{2}{|c|}{ Board independence } & \multicolumn{2}{|c|}{ Herfindahl Index } & \multicolumn{2}{|c|}{ Market share } \\
\hline & $\begin{array}{c}\geq \text { median } \\
\text { (1) }\end{array}$ & $\begin{array}{c}<\text { median } \\
\text { (2) }\end{array}$ & $\begin{array}{c}\geq 0.1 \\
(3)\end{array}$ & $\begin{array}{c}<0.1 \\
(4)\end{array}$ & $\begin{array}{c}\geq \text { Industry } \\
\text { median } \\
\text { (5) }\end{array}$ & $\begin{array}{c}<\text { Industry } \\
\text { median } \\
(6)\end{array}$ \\
\hline$\Delta$ Capex & $\begin{array}{c}0.057 \\
{[0.271]}\end{array}$ & $\begin{array}{c}0.267 \\
{[0.977]}\end{array}$ & $\begin{array}{c}-0.042 \\
{[-0.103]}\end{array}$ & $\begin{array}{c}0.225 \\
{[1.038]}\end{array}$ & $\begin{array}{c}0.188 \\
{[0.868]}\end{array}$ & $\begin{array}{c}0.362 \\
{[1.109]}\end{array}$ \\
\hline $\begin{array}{l}\text { Insurance coverage ratio } \\
* \Delta \text { Capex }\end{array}$ & $\begin{array}{l}1.656^{*} \\
{[1.660]}\end{array}$ & $\begin{array}{l}-2.984^{* *} \\
{[-2.130]}\end{array}$ & $\begin{array}{l}-1.204 \\
{[-0.993]}\end{array}$ & $\begin{array}{l}1.694^{* *} \\
{[2.084]}\end{array}$ & $\begin{array}{l}-1.830^{*} \\
{[-1.928]}\end{array}$ & $\begin{array}{c}0.924 \\
{[0.757]}\end{array}$ \\
\hline Insurance coverage ratio & $\begin{array}{c}-0.560^{* * *} \\
{[-2.753]}\end{array}$ & $\begin{array}{l}-0.798^{* *} \\
{[-1.997]}\end{array}$ & $\begin{array}{l}-0.410^{*} \\
{[-1.656]}\end{array}$ & $\begin{array}{l}-0.707^{* * *} \\
{[-2.644]}\end{array}$ & $\begin{array}{l}-0.389^{* *} \\
{[-2.037]}\end{array}$ & $\begin{array}{c}-0.894 \\
{[-1.418]}\end{array}$ \\
\hline Capex (lagged) & $\begin{array}{c}0.367 \\
{[1.153]}\end{array}$ & $\begin{array}{l}1.078^{* *} \\
{[2.303]}\end{array}$ & $\begin{array}{c}0.406 \\
{[0.857]}\end{array}$ & $\begin{array}{l}0.760^{* *} \\
{[2.213]}\end{array}$ & $\begin{array}{l}0.613^{*} \\
{[1.746]}\end{array}$ & $\begin{array}{l}1.311^{* *} \\
{[2.520]}\end{array}$ \\
\hline Leverage & $\begin{array}{c}-0.886^{* * *} \\
{[-4.696]}\end{array}$ & $\begin{array}{c}-0.735^{* * *} \\
{[-2.719]}\end{array}$ & $\begin{array}{c}-0.791^{* * *} \\
{[-3.507]}\end{array}$ & $\begin{array}{c}-1.045^{* * *} \\
{[-4.150]}\end{array}$ & $\begin{array}{c}-0.783^{* * *} \\
{[-4.869]}\end{array}$ & $\begin{array}{l}-1.625^{* *} \\
{[-2.588]}\end{array}$ \\
\hline$\Delta$ Earnings & $\begin{array}{l}0.554^{* * *} \\
{[3.772]}\end{array}$ & $\begin{array}{l}0.760^{* * *} \\
{[2.842]}\end{array}$ & $\begin{array}{l}0.373^{* *} \\
{[2.192]}\end{array}$ & $\begin{array}{l}0.724^{* * *} \\
{[3.301]}\end{array}$ & $\begin{array}{l}0.630^{* * *} \\
{[4.170]}\end{array}$ & $\begin{array}{c}0.360 \\
{[0.768]}\end{array}$ \\
\hline$\Delta$ Net assets & $\begin{array}{c}-0.066 \\
{[-1.389]}\end{array}$ & $\begin{array}{c}0.095 \\
{[1.004]}\end{array}$ & $\begin{array}{c}-0.048 \\
{[-0.559]}\end{array}$ & $\begin{array}{c}0.061 \\
{[0.746]}\end{array}$ & $\begin{array}{c}0.020 \\
{[0.379]}\end{array}$ & $\begin{array}{c}-0.024 \\
{[-0.095]}\end{array}$ \\
\hline$\Delta \mathrm{R} \& \mathrm{D}$ & $\begin{array}{c}6.172^{*} \\
{[1.952]}\end{array}$ & $\begin{array}{c}6.498 \\
{[1.307]}\end{array}$ & $\begin{array}{c}4.962^{*} \\
{[1.731]}\end{array}$ & $\begin{array}{c}6.579 \\
{[1.088]}\end{array}$ & $\begin{array}{c}2.786 \\
{[0.919]}\end{array}$ & $\begin{array}{c}16.799^{* * *} \\
{[3.011]}\end{array}$ \\
\hline$\Delta$ Interest & $\begin{array}{c}-0.690 \\
{[-0.493]}\end{array}$ & $\begin{array}{c}-0.793 \\
{[-0.361]}\end{array}$ & $\begin{array}{c}-1.066 \\
{[-0.682]}\end{array}$ & $\begin{array}{c}-0.649 \\
{[-0.300]}\end{array}$ & $\begin{array}{l}-2.455^{*} \\
{[-1.826]}\end{array}$ & $\begin{array}{c}4.669 \\
{[1.289]}\end{array}$ \\
\hline$\Delta$ Dividends & $\begin{array}{c}-1.645 \\
{[-1.577]}\end{array}$ & $\begin{array}{c}-0.185 \\
{[-0.176]}\end{array}$ & $\begin{array}{c}-0.305 \\
{[-0.251]}\end{array}$ & $\begin{array}{c}-1.540 \\
{[-1.513]}\end{array}$ & $\begin{array}{c}-0.803 \\
{[-1.230]}\end{array}$ & $\begin{array}{l}-109.32 \\
{[-0.779]}\end{array}$ \\
\hline Net financing & $\begin{array}{c}0.123 \\
{[1.069]}\end{array}$ & $\begin{array}{c}0.101 \\
{[0.668]}\end{array}$ & $\begin{array}{c}0.205 \\
{[1.590]}\end{array}$ & $\begin{array}{c}0.039 \\
{[0.254]}\end{array}$ & $\begin{array}{c}0.051 \\
{[0.565]}\end{array}$ & $\begin{array}{c}0.106 \\
{[0.247]}\end{array}$ \\
\hline$\Delta$ Cash & $\begin{array}{l}0.630^{* * *} \\
{[2.967]}\end{array}$ & $\begin{array}{l}0.880^{* * *} \\
{[2.774]}\end{array}$ & $\begin{array}{l}1.154^{* * *} \\
{[3.482]}\end{array}$ & $\begin{array}{l}0.699^{* * *} \\
{[2.706]}\end{array}$ & $\begin{array}{l}0.825^{* * *} \\
{[3.824]}\end{array}$ & $\begin{array}{l}1.254^{* *} \\
{[2.602]}\end{array}$ \\
\hline Cash (lagged) & $\begin{array}{c}0.199 \\
{[1.433]}\end{array}$ & $\begin{array}{l}0.500^{* *} \\
{[2.084]}\end{array}$ & $\begin{array}{l}0.422^{* *} \\
{[2.157]}\end{array}$ & $\begin{array}{c}0.129 \\
{[0.701]}\end{array}$ & $\begin{array}{c}0.140 \\
{[1.053]}\end{array}$ & $\begin{array}{c}0.792^{*} \\
{[1.937]}\end{array}$ \\
\hline Industry effects & Yes & Yes & Yes & Yes & Yes & Yes \\
\hline Year effects & Yes & Yes & Yes & Yes & Yes & Yes \\
\hline Adjusted $R^{2}$ & 0.209 & 0.267 & 0.190 & 0.281 & 0.229 & 0.271 \\
\hline$N$ & 839 & 613 & 862 & 689 & 1,309 & 242 \\
\hline
\end{tabular}




\section{Table 10}

Directors' and officers' insurance coverage and loan spreads - robustness tests.

Column 1 shows the results from an ordinary least squares (OLS) regression of loan spreads on excess D\&O insurance coverage, defined as the residual coverage amount (in dollars) scaled by the average market value of equity in the year. The residual coverage amount is obtained from a D\&O insurance coverage prediction model similar to that in Core (1997), in which the dependent variable is the log policy limit and the explanatory variables include log market value of equity, leverage, cash holdings, profitability, Herfindahl Index, and indicator variables for US listing, board independence, and having a prior divestiture. We also include industry and year fixed effects in the insurance coverage prediction model. Column 2 shows the results from an OLS regression of loan spreads on the $\mathrm{D} \& \mathrm{O}$ insurance coverage, controlling for insurance premiums as an additional governance control. Column 3 shows the results from an OLS regression of loan spreads on excess D\&O insurance coverage (defined above) and excess insurance price. We follow the approach in Chalmers, Dann, and Harford (2002) and Core (2000) to estimate the excess insurance price (premium) as the residual from the model that regresses insurance premiums on excess coverage and all variables used in the excess coverage model scaled by the amount of coverage. Column 4 shows the results from an OLS regression of loan spreads on D\&O insurance coverage ratio excluding loan facilities originated in National Bureau of Economic Research recession years (i.e., 2001 and 2008 in our sample period). Column 5 controls for the effect of economy-wide credit spreads, defined as the yield on (US) AAA-rated corporate bonds minus the three-month London Interbank Offered Rate (LIBOR) (both measured at the loan origination date). Column 6 shows the results from a firm fixed effects regression. Column 7 shows the second-stage coefficients from regressing loan spreads on instruments for the $\mathrm{D} \& \mathrm{O}$ insurance coverage ratio. The insurance coverage ratio is instrumented with fitted values from a first-stage regression of the $\mathrm{D} \& \mathrm{O}$ insurance coverage ratio on the industry/year median insurance coverage ratio (based on Fama and French 30 industry classifications) and other control variables. Shea's partial $R^{2}$ is a measure of instrumental variable (IV) relevance. First-stage $F$-test is the test of excluded IV in the first-stage regression. In all columns loan spreads are measured in percentage points. The coefficients on the constant and any included fixed effects are omitted for brevity. Standard errors (clustered at the firm level) that are robust to both cross-sectional heteroskedasticity and within-firm serial correlation are used in computing $t$-statistics (in square brackets). ${ }^{*},{ }^{* *}$, or ${ }^{* * *}$ indicates that the coefficient is statistically significantly different from zero at the $0.10,0.05$, or 0.01 level using a two-tailed $t$-test, respectively. Variable definitions are in Table 1 .

\begin{tabular}{|c|c|c|c|c|c|c|c|}
\hline Independent variable & $(1)$ & (2) & (3) & (4) & (5) & (6) & (7) \\
\hline Excess coverage ratio & $\begin{array}{l}0.848^{* * *} \\
{[2.664]}\end{array}$ & & $\begin{array}{c}0.604^{*} \\
{[1.740]}\end{array}$ & & & & \\
\hline Insurance coverage ratio & & $\begin{array}{l}1.313^{* * *} \\
{[2.833]}\end{array}$ & & $\begin{array}{l}1.459^{* * *} \\
{[3.227]}\end{array}$ & $\begin{array}{l}1.347^{* * *} \\
{[2.938]}\end{array}$ & $\begin{array}{l}1.299^{* *} \\
{[2.377]}\end{array}$ & $\begin{array}{l}1.423^{* *} \\
{[1.997]}\end{array}$ \\
\hline Insurance price & & $\begin{array}{c}10.822^{* * *} \\
{[3.298]}\end{array}$ & & & & & \\
\hline Excess insurance price & & & $\begin{array}{l}18.516^{* *} \\
{[1.960]}\end{array}$ & & & & \\
\hline Ln(assets) & $\begin{array}{l}-0.185^{* * *} \\
{[-3.199]}\end{array}$ & $\begin{array}{c}-0.281^{* * *} \\
{[-4.216]}\end{array}$ & $\begin{array}{c}-0.251^{* * *} \\
{[-3.921]}\end{array}$ & $\begin{array}{c}-0.195^{* * *} \\
{[-3.221]}\end{array}$ & $\begin{array}{c}-0.197^{* * *} \\
{[-3.572]}\end{array}$ & $\begin{array}{l}-0.206^{*} \\
{[-1.952]}\end{array}$ & $\begin{array}{c}-0.209^{* * *} \\
{[-3.891]}\end{array}$ \\
\hline Market-to-book & $\begin{array}{c}-0.084 \\
{[-0.787]}\end{array}$ & $\begin{array}{c}0.041 \\
{[0.374]}\end{array}$ & $\begin{array}{c}0.026 \\
{[0.211]}\end{array}$ & $\begin{array}{c}0.038 \\
{[0.361]}\end{array}$ & $\begin{array}{c}-0.062 \\
{[-0.676]}\end{array}$ & $\begin{array}{l}-0.236^{* *} \\
{[-2.382]}\end{array}$ & $\begin{array}{c}-0.082 \\
{[-0.859]}\end{array}$ \\
\hline Profitability & $\begin{array}{c}-2.137^{* * *} \\
{[-2.814]}\end{array}$ & $\begin{array}{l}-1.591^{* *} \\
{[-2.022]}\end{array}$ & $\begin{array}{l}-1.706^{* *} \\
{[-2.095]}\end{array}$ & $\begin{array}{c}-2.694^{* * *} \\
{[-3.931]}\end{array}$ & $\begin{array}{l}-2.106^{* * *} \\
{[-3.255]}\end{array}$ & $\begin{array}{l}-1.742^{*} \\
{[-1.854]}\end{array}$ & $\begin{array}{c}-2.114^{* * *} \\
{[-3.162]}\end{array}$ \\
\hline Leverage & $\begin{array}{l}1.496^{* * *} \\
{[3.077]}\end{array}$ & $\begin{array}{l}0.901^{*} \\
{[1.785]}\end{array}$ & $\begin{array}{l}1.863^{* * *} \\
{[3.097]}\end{array}$ & $\begin{array}{c}0.824^{*} \\
{[1.772]}\end{array}$ & $\begin{array}{l}0.875^{* *} \\
{[2.033]}\end{array}$ & $\begin{array}{c}0.303 \\
{[0.543]}\end{array}$ & $\begin{array}{l}0.864^{*} \\
{[1.934]}\end{array}$ \\
\hline Cash flow volatility & $\begin{array}{l}0.182^{* * *} \\
{[2.869]}\end{array}$ & $\begin{array}{l}0.153^{* * *} \\
{[2.696]}\end{array}$ & $\begin{array}{l}0.196^{* * *} \\
{[3.246]}\end{array}$ & $\begin{array}{l}0.177^{* * *} \\
{[2.914]}\end{array}$ & $\begin{array}{l}0.153^{* *} \\
{[2.500]}\end{array}$ & $\begin{array}{l}0.166^{* *} \\
{[2.032]}\end{array}$ & $\begin{array}{l}0.156^{* *} \\
{[2.535]}\end{array}$ \\
\hline Tangibility & $\begin{array}{c}-0.243 \\
{[-0.633]}\end{array}$ & $\begin{array}{c}-0.114 \\
{[-0.265]}\end{array}$ & $\begin{array}{c}-0.059 \\
{[-0.134]}\end{array}$ & $\begin{array}{c}-0.299 \\
{[-0.837]}\end{array}$ & $\begin{array}{c}-0.325 \\
{[-0.910]}\end{array}$ & $\begin{array}{c}0.941 \\
{[1.354]}\end{array}$ & $\begin{array}{c}-0.278 \\
{[-0.750]}\end{array}$ \\
\hline Ln(loan size) & $\begin{array}{c}-0.191^{* * *} \\
{[-3.156]}\end{array}$ & $\begin{array}{c}-0.189^{* * *} \\
{[-3.152]}\end{array}$ & $\begin{array}{c}-0.210^{* * *} \\
{[-3.512]}\end{array}$ & $\begin{array}{c}-0.169^{* * *} \\
{[-2.818]}\end{array}$ & $\begin{array}{c}-0.179^{* * *} \\
{[-3.090]}\end{array}$ & $\begin{array}{c}-0.172^{* * *} \\
{[-2.664]}\end{array}$ & $\begin{array}{c}-0.175^{* * *} \\
{[-3.013]}\end{array}$ \\
\hline Performance pricing (1/0) & -0.011 & 0.047 & 0.091 & -0.131 & -0.061 & 0.086 & -0.031 \\
\hline
\end{tabular}




\begin{tabular}{|c|c|c|c|c|c|c|c|}
\hline & {$[-0.098]$} & {$[0.409]$} & {$[0.806]$} & {$[-1.140]$} & {$[-0.549]$} & {$[0.700]$} & {$[-0.281]$} \\
\hline \multirow[t]{2}{*}{ Independent directors } & -0.396 & -0.335 & -0.202 & $-0.858^{*}$ & -0.689 & -0.407 & -0.558 \\
\hline & {$[-0.905]$} & {$[-0.620]$} & {$[-0.372]$} & {$[-1.871]$} & {$[-1.607]$} & {$[-0.573]$} & {$[-1.215]$} \\
\hline \multirow[t]{2}{*}{ Blockholder (1/0) } & -0.132 & -0.158 & -0.123 & -0.090 & -0.121 & & -0.143 \\
\hline & {$[-0.997]$} & {$[-1.067]$} & {$[-0.843]$} & {$[-0.671]$} & {$[-1.014]$} & & {$[-1.124]$} \\
\hline \multirow[t]{2}{*}{ Duality (1/0) } & -0.124 & -0.125 & -0.181 & 0.010 & -0.092 & & -0.090 \\
\hline & {$[-0.562]$} & {$[-0.557]$} & {$[-0.814]$} & {$[0.050]$} & {$[-0.448]$} & & {$[-0.415]$} \\
\hline \multirow[t]{2}{*}{ Dual-class (1/0) } & 0.176 & $0.528^{* *}$ & $0.458^{* *}$ & $0.394^{*}$ & 0.278 & & 0.240 \\
\hline & {$[0.973]$} & {$[2.180]$} & [2.048] & [1.712] & [1.411] & & [1.208] \\
\hline \multirow[t]{2}{*}{ Herfindahl Index } & 0.122 & 0.225 & 0.362 & 0.465 & 0.078 & -0.179 & -0.034 \\
\hline & {$[0.213]$} & {$[0.253]$} & {$[0.430]$} & {$[0.796]$} & {$[0.142]$} & {$[-0.267]$} & {$[-0.062]$} \\
\hline \multirow[t]{2}{*}{ Credit spread } & & & & & $0.280^{* * *}$ & & \\
\hline & & & & & [3.054] & & \\
\hline Credit rating indicators & Yes & Yes & Yes & Yes & Yes & Yes & Yes \\
\hline Loan type indicators & Yes & Yes & Yes & Yes & Yes & Yes & Yes \\
\hline Loan purpose indicators & Yes & Yes & Yes & Yes & Yes & Yes & Yes \\
\hline Firm effects & No & No & No & No & No & Yes & No \\
\hline Industry effects & Yes & Yes & Yes & Yes & Yes & Yes & Yes \\
\hline Year effects & Yes & Yes & Yes & Yes & Yes & Yes & Yes \\
\hline First-stage Shea's partial $R^{2}$ & & & & & & & 0.471 \\
\hline First-stage $F$-test ( $p$-value) & & & & & & & 0.000 \\
\hline Adjusted $R^{2}$ & 0.528 & 0.592 & 0.619 & 0.544 & 0.533 & 0.704 & 0.517 \\
\hline$N$ & 520 & 401 & 384 & 446 & 546 & 560 & 546 \\
\hline
\end{tabular}




\section{Table 11}

Directors' and officers' insurance coverage and bond spreads.

This table contains the results of ordinary least squares regressions of at-issuance bond spreads (at-issuance bond yields minus the yield on zero-coupon government bonds with the same time to maturity when the bond was issued) on D\&O insurance coverage ratios. The bond issuance data for Canadian issuers is primarily taken from Bloomberg and is supplemented by data from the Mergent Fixed Income Securities Database. The mean bond spread is 261.6 basis points and the standard deviation is 171.0 basis points. We exclude financial firms from the analysis and exclude bonds with missing or negative spreads. Bond spreads are measured in percentage points. The coefficients on the constant, year and industry fixed effects, and credit rating indicators are omitted for brevity. Standard errors (clustered at the firm level) that are robust to both cross-sectional heteroskedasticity and withinfirm serial correlation are used in computing $t$-statistics (in square brackets). ${ }^{*},{ }^{* *}$, or ${ }^{* * *}$ indicates that the coefficient is statistically significantly different from zero at the $0.10,0.05$, or 0.01 level using a two-tailed $t$-test, respectively. Variable definitions are in Table 1.

\begin{tabular}{|c|c|c|}
\hline Independent variable & (1) & (2) \\
\hline Insurance coverage ratio & $\begin{array}{l}3.498^{* * *} \\
{[4.389]}\end{array}$ & $\begin{array}{l}3.151^{* * *} \\
{[4.280]}\end{array}$ \\
\hline Ln(assets) & $\begin{array}{c}-0.191 \\
{[-1.398]}\end{array}$ & $\begin{array}{l}-0.307^{* *} \\
{[-2.097]}\end{array}$ \\
\hline Market-to-book & $\begin{array}{l}-0.482^{* *} \\
{[-2.269]}\end{array}$ & $\begin{array}{c}-0.180 \\
{[-0.831]}\end{array}$ \\
\hline Profitability & $\begin{array}{c}-0.679 \\
{[-0.649]}\end{array}$ & $\begin{array}{c}-0.283 \\
{[-0.228]}\end{array}$ \\
\hline Leverage & $\begin{array}{c}0.799 \\
{[1.071]}\end{array}$ & $\begin{array}{c}1.364 \\
{[1.622]}\end{array}$ \\
\hline Cash flow volatility & $\begin{array}{l}0.329^{* *} \\
{[1.991]}\end{array}$ & $\begin{array}{c}0.094 \\
{[0.882]}\end{array}$ \\
\hline Tangibility & $\begin{array}{c}-1.116 \\
{[-1.255]}\end{array}$ & $\begin{array}{c}-0.521 \\
{[-0.603]}\end{array}$ \\
\hline Ln(bond size) & $\begin{array}{l}0.358^{* *} \\
{[2.378]}\end{array}$ & $\begin{array}{c}-0.145 \\
{[-1.386]}\end{array}$ \\
\hline Convertible (1/0) & $\begin{array}{c}-0.721 \\
{[-1.579]}\end{array}$ & $\begin{array}{c}-0.382 \\
{[-0.797]}\end{array}$ \\
\hline Callable (1/0) & $\begin{array}{c}-0.001 \\
{[-0.002]}\end{array}$ & $\begin{array}{l}0.409 * \\
{[1.674]}\end{array}$ \\
\hline Independent directors & & $\begin{array}{c}0.055 \\
{[0.077]}\end{array}$ \\
\hline Blockholder (1/0) & & $\begin{array}{c}0.342 \\
{[1.529]}\end{array}$ \\
\hline Duality (1/0) & & $\begin{array}{c}0.254 \\
{[0.849]}\end{array}$ \\
\hline Dual-class (1/0) & & $\begin{array}{c}0.485 \\
{[1.059]}\end{array}$ \\
\hline Herfindahl Index & & $\begin{array}{c}2.407 \\
{[1.512]}\end{array}$ \\
\hline Credit rating indicators & Yes & Yes \\
\hline Industry effects & Yes & Yes \\
\hline Year effects & No & Yes \\
\hline Adjusted $R^{2}$ & 0.453 & 0.650 \\
\hline$N$ & 328 & 276 \\
\hline
\end{tabular}


